\title{
Hatay Büyükşehir Belediyesi
}

\section{Hatay Metropolitan Municipality}

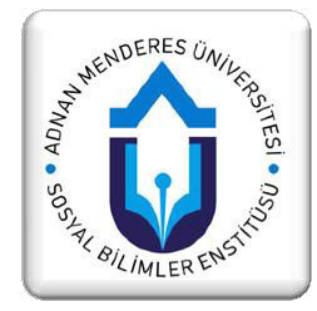

\section{Özet}

6360 sayılı Yasa kapsamında kurulanlarla birlikte, Türkiye'de büyükşehir belediyesi sayısı otuza yükselmiştir. Yeni yasa, büyükşehir belediyelerinin sınırını ilin mülki sınırları ile örtüştürmüştür. Hatay Büyükşehir Belediyesi de 6360 sayllı Yasa ile kurulmuş olan büyükşehir belediyelerinden biridir. Hatay'da büyükşehir kurulması ile ilde yeni bir yönetsel yapı ortaya çıkmıştır. ilde büyükşehir belediyesi kurulmasının yönetsel etkilerinin yanı sıra siyasal, mali, kentsel ve sosyal etkileri de söz konusudur. Özellikle büyük ilçelerin bölünmesi yöntemiyle yeni ilçelerin kurulması ve bazı ilçelerin sınırlarının değiştirilmesinin önemli siyasal etkileri olmuştur. Bu siyasal etkiler 2014 Yerel Seçimlerinde somut olarak ortaya çıkmıştır. Hatay'da büyükşehir belediyesi kurulmuş olmasının ilin gelişimi, altyapı sorunları, kentsel alanların planlanması vb. gibi konularda katkılarının ne yönde olacağı, gelecek dönemlerdeki uygulama süreci içerisinde görülecektir.

Anahtar Sözcükler: 6360 Sayılı Yasa, Büyükşehir Belediyesi, Hatay ili, Hatay Büyükşehir Belediyesi

\section{Abstract}

The number of metropolitan municipalities in Turkey has increased to thirty in the context of the law number 6360 together with newly established. The new law has overlapped the metropolitan municipal borders with the provincial borders. Hatay metropolitan municipality is also one of newly established metropolitan municipalities under the law number 6360. A new administrative structure has emerged in the province after becoming the metropolitan municipalities of Hatay. Not only the administrative effects of the law in the province, it has been also observed that there are political, financial, urban and social effects in the agenda. In particular, after the foundation of new districts thanks to the way of dividing of large districts, and the alteration of some districts' border have caused the significant political effects. These political effects have been concretely appeared in the *Yrd. Doc. Dr Mustafa Kemal Üniversitesi Íktisadi ve İdari Bilimler Fakültesi Kamu Yönetimi Bölümü results of the 2014 local election in Turkey. To what extent the formation of a metropolitan municipality in Hatay will contribute to the issues of development, infrastructure, and the planning of urban area so others are to be seen in practice in the following periods.

Keywords: The Law Number 6360, Metropolitan Municipality, Hatay Province, Hatay Metropolitan Municipality 


\section{GİRIŞ}

Türkiye'de II. Dünya Savaşı sonrasında, özellikle de 1950'li yıllarda yaşanan hızlı kentleşme süreci, metropoliten kentlerde "yönetim" sorununu gündeme getirmiştir. Bu bağlamda, 1961 Anayasası'nın sağlamış olduğu ortam içerisinde tartışılan konulardan birisi de "metropoliten alanların yönetimi" sorunudur. Bu sorunla ilgili uygulamaya konulan geçici çözümler sonrasında, bütüncül yasal düzenlemeler ancak 1980'li yıllarda gündeme gelebilmiştir. Bilindiği gibi, Türkiye'de, "büyükşehir belediye dizgesi" temelini 1982 Anayasası'ndan almış ve 1984 yılında 3030 sayılı Büyükşehir Belediyesi Yasası çıkarılmıştır. 3030 sayı1ı Yasa, belediye sınırları içerisinde birden fazla ilçe bulunan kentleri büyük kent olarak tanımlamış, büyükşehir belediyesi ve ilçe belediyesi olmak üzere iki düzeyli ve merkezi bir anakent yapısı öngörmüştür (Keleş, 2004: 375).1984 yllındaki yerel seçimler ile bu düzenlemelere paralel uygulama İstanbul, Ankara ve İzmir'de başlatılmıştır. Daha sonra büyükşehir dizgesinde ikinci kuşak olarak adlandırılan büyükşehir belediyeleri kurulmuştur. Bu doğrultuda Adana 1986 yılında, Bursa, Gaziantep ve Konya 1987 yılında, Kayseri ise 1988 yılında büyükşehir statüsüne kavuşmuştur. Böylece büyükşehir sayısı sekize yükselmiştir (Özgür vd., 2007).Büyükşehir Belediyesi Yasası, büyükşehir statüsünde bulunan belediyelere ek mali olanaklar sağlamış olması nedeniyle, orta büyüklükteki birçok kentte büyükşehir olma yönünde çabalar da yoğunlaşmış ve yerel kamuoylarında beklentiler oluşmuştur. Bu durum karşısında çeşitli dönemlerde çıkarılan kanun hükmünde kararnamelerle büyükşehir olma niteliklerine sahip olmayan bazı belediyeler de büyükşehir belediyesi statüsüne kavuşmuştur (Ulusoy ve Akdemir, 2013: 308). Örneğin, 1993 y1lında çıkarılan 504 No'lu Kanun Hükmünde Kararname ile kurulmuş olan ve üçüncü kuşak olarak adlandırılan Antalya, Diyarbakır, Erzurum, Eskişehir, İzmit, Mersin ve Samsun Büyükşehir Belediyeleri, öncekilerden farklı bir statüdedir. 2000 yılında 593 sayılı Kanun Hükmünde Kararname ile Adapazarı Büyükşehir Belediyesi kurulmuş, böylece Türkiye'de büyükşehir belediyesi sayısı da 16'ya yükselmiştir.

2004 yılında yürürlüğe giren 5216 sayılı yasa, yeni büyükş̧ehir belediyesi kuruluşunu zorlaştırmış, büyükşehir belediyesi kurulabilmesi için bir il merkezi belediyede ve o belediyenin sinırlarına 10 kilometrelik bir mesafe içerisinde yaşayan nüfusun 750.000'den fazla olması, asgari şartlardan en önemlisidir. Büyükşehir statüsünün zorunlu ve somut bir "nüfus" önkoşuluna bağlanmış olması, büyükşehir statüsüne kavuşma özlemi taşıyan birçok kentte olduğu gibi, Antakya özelinde Hatay'da da ortaya çıkmış olan beklentilerin zora girmesine neden olmuş ve hayal kırıklığ 1 yaratmıştır. 2011 y1lı genel seçimleri sürecinde gündeme gelen Antakya Büyükşehir Belediyesi tartışmalarının yapıldığı dönemde, Antakya kentinin ve kent özeği ile arasında kentbilim açısından ilişki kurulabilecek yerleşim birimlerinin nüfuslarının toplamı ancak 400.000 civarındaydı. Antakya kentsel alanının sahip olduğu bu nüfus miktarı büyükşehir kurulabilmesi için gerekli ölçütün çok altındaydı. Bu nedenle de Antakya ve diğer beklenti içerisinde olan orta büyüklükteki kentlerde büyükşehir belediyesi kurulabilmesi için, ya 5216 sayılı Yasanın koymuş olduğu nüfus ölçütü aşağıya çekilmeli ya da farklı bir yaklaşım ile yeni bir yasal düzenlemeye gidilmeliydi. İşte 6360 sayılı Yasa'nın bu yeni yaklaşımın bir ürünü olduğunu söyleyebiliriz. 2012 yılının Kasım ayında çıkarılan 6360 sayılı Yasa, büyükşehir belediyesi yapısında çok önemli değişiklikleri de beraberinde getirmiş ve bu yasayla büyükşehir belediyesi sınırları ilin mülki sınırları ile örtüştürülmüştür. Yeni yasada, "toplam nüfusu 750.000'den fazla olan illerin il belediyeleri kanunla büyükşehir belediyesine dönüştürülebilir" biçimindeki düzenleme sonucunda, aralarında Hatay İli'nin de olduğu 13 ilde daha büyükşehir belediyesi kurulmuştur. Daha sonra 2013 yılı Mart ayında yürürlüğe giren 6447 sayılı Yasa ile Ordu İli’nde de büyükşehir belediyesi kurulmuş, böylece Türkiye'deki büyükşehir belediyesi sayısı 30'a ulaşmıştır.

Kentsel alanlarla birlikte ilin tamamını kapsayan bir statüde büyükşehir belediyesi kurulması, diğer illerde olduğu gibi Hatay İli’nde de sorunlu bir yerel yönetim sürecinin kapısını aralamıştır. Bu sürecin Hatay büyükşehir belediyesi uygulamalarında, gerek yasanın kendi kurgusundan kaynaklanan nedenler, gerekse Hatay İli'ne özgü farklı coğrafi özellikler ve sosyal doku vb. gibi nedenlerle daha "sorunlu" yaşanabilme olasılığı bulunmaktadır. Bu çalışma kapsamında, öncelikle genel hatlarıyla Hatay İli tanıtılmış, ilin mekansal gelişimi ve 6360 sayılı Yasa öncesindeki yerel-yönetsel yapısı ile ilgili değerlendirmelere yer verilmiştir. Çalışmamızın sonraki bölümlerinde ise hem yeni yasanın hem de Hatay’da büyükşehir belediyesi kurulmasının yönetsel, siyasal, mali ve kentsel etkileri irdelenmeye çalışılmıştır. 


\section{HATAY ILI'NIN GENEL TANITIMI}

Günümüzde Hatay İli’nin bulunduğu yerleşim alanları, Türkiye'nin en eski yerleşim alanlarından biridir. Hatay İli'nin merkezi olan Antakya Kenti'nin kuruluşu antik dönemlere kadar uzanır. Kent, Büyük İskender'in komutanlarından Nikatoreleukos tarafindan babası Antiochus'un anısına M.Ö. 300 yılında kurulmuştur. Antakya Kenti tarihsel süreç içerisinde önemli depremler ve savaşlara sahne olmuş, çok önemli yıkımlar yaşamış ve birçok kez el değiştirmiştir. Ancak buna rağmen Antakya kenti, çok önemli tarihsel bir mirası da günümüze kadar taşıyabilmiştir. Bilindiği gibi, Türkiye Cumhuriyet'i kurulurken, İskenderun Sancağı Misak-1 Milli sınırları içerisinde olduğu halde ülke toprakları dışında kalmıştı. 1936 yılında bizzat Mustafa Kemal Atatürk, İskenderun Sancağı'nın ismini, "Hatay Sancağı" olarak değiştirerek "Hatay" sözcügünü Türkçeye kazandırmıştır. Sancak, 7 Eylül 1938'de bağımsızlığııı ilan ederek, "Hatay Devleti" adını almış, 29 Haziran 1939 tarihinde toplanan Hatay Millet Meclisi Türkiye’ye katılma kararı vermiştir. 7 Temmuz 1939 tarihinde de 3711 sayılı Kanunla Hatay Vilayeti kurulmuştur (Tekin, 2008: 321).

Hatay Türkiye'nin en güneyinde ve Akdeniz'in doğu şeridinde $35^{\circ} 52^{\prime}-37^{\circ} 4^{\prime}$ kuzey enlemleri ile $35^{\circ} 40^{\prime}-36^{\circ} 35^{\prime}$ boylamları arasında yer alır. Yüzölçümü $5867 \mathrm{~km}^{2}$ olan ilin, 175,6 km. uzunluğundaki batı sınırını Akdeniz oluşturur. Kuzey sınır idari bir sınır olup 96,3 km. uzunluğundadır. İlin doğu ve güneyindeki $276,9 \mathrm{~km}$. uzunluğundaki Türkiye - Suriye sınırı ise siyasi sınır özelliğindedir. Hatay İli tarım, sanayi, turizm, doğa, tarihsel ve kültürel zenginlikler vb. özellikleri ile eşine az rastlanır bir potansiyele sahiptir. Anavatana katıldığı 1939 yılından itibaren büyük bir gelişim sergilese de mevcut potansiyeli göz önünde bulundurulduğunda, söz konusu gelişimi istendik seviyelerde olmamıştır (Tek, 2009a). Hatay, il nüfusunun büyüklüğü açısından 13. sırada, nüfus yoğunluğu bakımında da 6. sırada yer almaktadır. İl ve ilçe merkezi nüfusu açısından ise 16. sırada bulunmaktadır. Ancak Hatay İli, nüfus büyüklügünün yanı sıra, azımsanmayacak bir kırsal (belde ve köy) nüfusuna sahiptir. Belde ve köy nüfusunun büyüklüğü açısından Türkiye'de 2. sırada yer almaktadır. Kırsal nüfusun toplam nüfusa oranı açısından bakıldığında ise \% 49.94'lük değer ile 8. sırada yer almaktadır.

Topraklarının yarısı (270.766 hektar) tarım alanı olan Hatay İli’nin ekonomisi, tarım başta olmak üzere ticaret ve sanayi ağırlıklıdır. Adını sonradan kurutulmuş olan Amik Gölü’nden almış olan Amik Ovası, bölgenin önemli tahıl ambarlarındandır. Türkiye'nin en büyük demir-çelik işletmesi İskenderun İlçesi'nde bulunmaktadır. Hatay İli, ülke sanayisine ve ekonomisine katkısı bakımından son dönemlerde yükselişe geçmiştir. TÜİK (2012) verilerine göre, ülke ihracatına katkıda tüm iller arasında 9. sırada bulunurken, ithalatta 7. sırada, gelişmişliğin önemli bir göstergesi olan elektrik tüketiminde de ise 8 . sırada bulunmaktadır.

\section{HATAY VE ANTAKYA KENTSEL ALANININ MEKÂNSAL GELİSịiMi}

Amanos Dağları (Nur Dağları) kuzeyden güneye Hatay İli’ni ikiye bölmektedir. Amanos Dağları, aynı zamanda ilde tarım, sanayi ve ticaretin dağılımını da etkileyen önemli bir faktör olmuştur. Geniş tarım alanlarının bulunduğu ve oldukça büyük bir alan kaplayan Amik Ovası Amanos Dağları'nın doğusunda, İskenderun- Payas aksı üzerindeki sanayi bölgesi ise batısında yer almaktadır. Genel olarak ilde tarım ve ticaret, ilin doğu bölgesinde, sanayi ise ağırlıklı olarak batı bölgesinde yoğunlaşmıştır. İlin demografik dağılımı incelendiğinde nüfusun tarım, ticaret ve sanayi merkezlerinde yoğunlaştığı görülmektedir. Örneğin, ilin ticaret merkezi olarak bilinen Antakya ve çevresinde yaklaşık olarak 470.000, sanayi merkezi olarak bilenen İskenderun, Payas, Dörtyol ve çevresinde 470.000, ayrıca önemli ölçüde Amik Ovası'nın tarım potansiyelinden yararlanmakta olan Kırıkhan-Reyhanlı ve çevresinde ise 200.000 dolayında nüfus mevcuttur.

Günümüzde Hatay Büyükşsehir Belediyesi’nin merkezi olan Antakya İlçesi, kuzeyde Amanos Dağları ile güneyde Kel Dağ (Cebel-i Akra) arasında kalan Aşağı Asi Vadisi'nin başlangıcında, Habib Neccar Dağı'nın eteklerinde yer almaktadır. Antakya kentsel alanı, önceleri merkez ilçe olan Antakya etrafında gelişmiş ve biçimlenmiştir. Ortasında Antakya'nın bulunduğu bu kentsel alan, son yıllarda artan 
nüfusu ve gelişen ekonomik yapısıyla dikkat çekmektedir. Ancak kuzey-güney doğrultusunda $30 \mathrm{~km}$. ve doğu-batı doğrultusunda $20 \mathrm{~km}$. büyüklügünde, neredeyse kesintisiz bir biçimde devam eden bu kentsel alanın dağınık, yaygın ve plansız bir yerleşim alanı olduğunu söylemek mümkündür. Antakya kentine kuzey yönünden yaklaşıldığında, Antakya ilçe merkezine $25 \mathrm{~km}$. kala başlayan ve aralıksız devam eden bir yapılaşma örüntüsü ile karşılaşılmaktadır. Söz konusu yapılaşma, belirli bir bütünsellikten yoksun, plansız, parçalı, dağınık, estetik açıdan sorunlu ve çarpık bir durum sergilemektedir. "Balık kılçı̆̆ı" formunda dağılım gösteren bu yapılaşma biçimine dışarıdan bakan bir gözlemcinin, kent merkezini kestirmesi ve yerleşim birimlerinin sınırlarını tahmin etmesi oldukça güçtür. Antakya'nın kuzey bölgesi için geçerli olan durum, Antakya'nın batı, doğu ve güney bölgeleri için de geçerlilik göstermektedir (Adıgüzel ve Tek, 2011: $83)$.

$\mathrm{Bu}$ çarpık kentsel alanın önemli bir öğesi olan ve tarihsel süreç içerisinde önemli uygarlıklara beşiklik eden Antakya kentinin, antik dönemlere kadar uzanan bir planlama öyküsü bulunmaktadır. Kentin ilk kuruluşunda uygulanmış olan "Hippodamos tarzı" şehircilik ilkeleri ile antik dönemin Antakya Kenti, Helenistik Çağ kentlerinin tipik bir örneğidir. Antakya'nın günümüz anlamındaki ilk imar planı ise 1948 yılında İller Bankası tarafından Asım Kömürcüoğlu'na yaptırılmıştır. Antakya Belediyesi'nin 1957 yılında Doç. Dr. Gündüz Özdeş'e yaptırmış olduğu ikinci imar planı 1/1000 ölçeğinde çizilmiştir. Bu plana göre kentin Asi Nehri'nin karşı yakasındaki gelişimi ile eski kentin imarı ve bu kesimin Reyhanlı ve Harbiye yönlerinde büyümesi planlanmıştır. Ancak planın asıl ağırlığını Asi'nin karşı tarafında gelişmeye başlayan yeni Antakya'nın gelişimi ve burada uygulanacak imar düzeni teşkil etmiştir. Bu planın kentin daha sonraki yıllar içerisinde göstermiş olduğu gelişme nedeniyle ihtiyaca cevap veremez hale gelmesi ve yapılan çok çeşitli imar tadilleriyle özelliğini büyük ölçüde kaybetmesi nedeniyle yeni bir imar planı ihtiyacı otaya çıkmıştır. Bu kapsamda 1978 yılında Antakya Belediyesi tarafından Yavuz Taşçı'ya yeni bir imar planı hazırlatılmıştır. Yeni imar planı çalışmaları sırasında, Gayrimenkul Eski Eserler ve Anıtlar Yüksek Kurulu 12.07.1975 tarihli 8521 sayılı kararı ile Antakya'da korumaya ilişkin ilk ciddi adımları atmıştır. Bu kararın eki olan ve Kültür Bakanlığı Eski Eserler ve Müzeler Genel Müdürlüğü’nce görevlendirilmiş olan tespit kurulunca hazırlanan takriben 1/2000 ölçekli bir harita üzerinde arkeolojik sit, kentsel sit ve doğal sit alaları ve sınırları belirlenmiş, anıtsal ve sivil mimarlık örneği 202 yapı tescil edilmiştir. Bu bağlamda bir "Koruma İmar Planı" yapılması hedefi doğrultusunda Antakya Belediyesi ile Ankara Devlet Mühendislik Mimarlık Akademisi Mimarlık Fakültesi Şehircilik Kürsüsü arasında bir sözleşme imzalanmıştır. Bu sözleşme gereğince yapılmış olan tespit çalışmaları sonucunda hazırlanan listeler 1982 yılında Gayrimenkul Eski Eserler ve Anıtlar Yüksek Kurulu'nca tescil edilmiştir. Seksenli yılların sonlarına doğru Gazi Üniversitesi Mühendislik Mimarlık Fakültesi çalışmalarını tamamlamış ve "Antakya Koruma İmar Planı" ve plan eki olan "Antakya Tarihi Sit Alanı Koruma İmar Planı Uygulama Yönetmeliği”, Taşınmaz Kültür ve Tabiat Varlıkları Koruma Yüksek Kurulu'nun 23.01.1987 tarihli kararı ile onaylanarak yürürlüğe girmiştir. Daha sonra, 1990 y1lında ise Antakya Belediyesi'nin yapmış olduğu başvurular doğrultusunda, Adana Kültür ve Tabiat Varlıkları Koruma Kurulu tarafından “Koruma İmar Planı”nda ve Uygulama Yönetmeliğinde önemli değişiklikler yapılmıştır. Hatay İli'nde büyükşehir belediyesi kurulana kadar, Antakya sit alanları içerisinde devam eden yapılaşma ve imar faaliyetleri bu plan ve uygulama yönetmeliği hükümlerine göre sürdürülmüştür (Demir, 1996: 210-216).

\section{HATAY'DA BÜYÜKŞEHİR BELEDIYYESİ KURULMADAN ÖNCE YEREL-YÖNETSEL YAPI}

19. Yüzyılda Halep eyaletine bağlı bir kaza olan Antakya'ya bağlı dört nahiye (Süveydiye, Cebel-i Akra, Kuseyr ve Altınözü) ve 310 köy bulunmaktaydı. Bu yüzyılın sonlarına doğru toplam nüfusunun 23.500 olduğu tahmin edilmektedir (Kara, 2005: 98). 7 Temmuz 1939 tarihinde de 3711 sayılı Kanunla Hatay Vilayeti kurulurken, merkez ilçe Antakya ile birlikte toplam 9 ilçesinin olduğu görülmektedir. Bu ilçeler: Antakya, İskenderun, Adana İli'ne bağlıyken Hatay İli'ne bağlanan Dörtyol ve Erzin, Kırıkhan, Yayladağı, Reyhanlı, Belen ve Hassa ilçeleridir. Hatay'ın anavatana katılım sonrasında, 1940 yılında yapılan nüfus sayımından günümüze Antakya metropoliten alanının nüfusunun düzenli bir artış eğilimi içerisinde olduğu görülmektedir. 1940 yılı nüfus sayımı sonuçlarına göre, Antakya (merkez) ilçesi, kent nüfusunun toplam nüfus içindeki yeri açısından, Kırıkhan, İskenderun ve Reyhanlı'dan sonra 4. sırada yer almaktadır. Antakya İlçesi içerisinde, 1945 yılında Altınözü, 1948 yılında ise Samandağ ilçeleri kurulmuştur. 
Hatay'ın merkez ilçesi olan Antakya'nın halk tarafından seçilmiş ilk belediye başkanı Necmettin Kuseyri'dir. Kuseyri 1963 yılında yapılmış olan yerel seçimlerinde Adalet Partisi adayı olarak belediye başkanı seçilmiştir. Bu tarihten sonra yapılan yerel seçimlerde sürekli olarak bir dönem sol kökenli, diğer dönem sağ kökenli adaylar Antakya belediye başkanlığını kazanmışlardır. Bu gelenek 2004 yılında sona ermiş, 2004 ve 2009 yerel seçimlerinde ise AKP'li adaylar belediye başkanlığını kazanmışlardır (Tek, 2009c).

6360 sayılı Yasa ile Hatay'da büyükşehir belediyesi kurulmadan önce Hatay İli'nde toplam olarak 12 ilçe bulunmaktaydı. Çizelge 1'e yansıdığ 1 gibi, özellikle Antakya ve çevresi kentsel alanının yanı sıra, İskenderun ve Samandağ ilçeleri etrafindaki kentsel alanlarda da çok sayıda belde belediyesinin bulunduğu görülmektedir.

Çizelge 1: 6360 Sayılı Yasa Öncesinde Hatay İli’ndeki Yönetim Birimleri

\begin{tabular}{|l|l|l|l|l|}
\hline \multicolumn{1}{|l|}{ İlçe } & Bucak & $\begin{array}{l}\text { Belde } \\
\text { Beld. }\end{array}$ & Köy & Mahalle \\
\hline Antakya & 5 & 21 & 70 & 43 \\
\hline Altınözü & 3 & 3 & 42 & 2 \\
\hline Belen & - & - & 11 & 6 \\
\hline Dörtyol & 2 & 6 & 6 & 7 \\
\hline Erzin & - & - & 10 & 10 \\
\hline Hassa & 2 & 5 & 28 & 6 \\
\hline İskenderun & 2 & 13 & 37 & 28 \\
\hline Kırıkhan & 2 & 1 & 56 & 16 \\
\hline Kumlu & - & - & 13 & 3 \\
\hline Reyhanlı & - & - & 31 & 16 \\
\hline Samandă̆ & 2 & 12 & 31 & 9 \\
\hline Yayladağı & 3 & 3 & 33 & 3 \\
\hline TOPLAM & 21 & 64 & 368 & 149 \\
\hline
\end{tabular}

Çizelge 1 ve 2'de görüldüğü gibi, Antakya kentsel alanının etrafinda6360 sayılı Yasa öncesinde daha çok belde belediyeleri ile ifade bulan bir yoğunluk söz konusuydu. Bu durum Antakya kentsel alnının ciddi ölçüde "yönetilememe sorunu" yaşanmasına neden olmaktaydı. Çizelge 1'e yansıdı̆̆ı gibi, Antakya Belediyesi'nin başta sınırdaş belde belediyeleri olmak üzere, diğer belde belediyeleri ve köyler ile çevrelenmiş ve sıkıştırılmış bir durumda olduğunu söylemek mümkündür. Antakya İlçesi'nde 21 belde belediyesi ve 70 köy bulunmaktaydı ki 6360 sayılı Yasa ile tüzel yapıları sona eren bu belde belediyelerinin büyük bölümü Antakya çevresinde ve Samandağ-Antakya-Kırıkhan aksının üzerinde yer almaktadır. Bu belde belediyelerinin tümü, 2'si dışında Antakya kentsel alanı içerisinde bulunmakta ve Çizelge 2'ye yansıdığı gibi, mesafe olarak il merkezine çok yakın konumları nedeniyle de Antakya Belediyesi'nin bütün hareket alanını çevrelemişlerdi.

Hatay İli'nde bulunan ve kentsel alanları çok yakından ilgilendiren, "belde belediyeleri sorunu" 1990'lı yıllarda, çevresine doğru yayılan ve saçaklanan Antakya kentsel alanında çok can yakıcı bir şekilde 
yaşanmaya başlanmıştır. Bu süreçte, batıdaki banliyöleşme (suburbanisation) sürecine benzer bir eğilim gözlenmiş, 1990'lı yıllarda ise ana kentin çevresinde yer alan bu yerleşim alanlarında, Güneş (2004)'in de vurgulamış olduğu gibi öngörüsüz ve akılcı olmayan kararlarla bir ya da iki mahalleden ya da köylerden oluşturulan küçük belde belediyeleri kurulmuştur.

Çizelge 2:6360 Sayılı Yasa Öncesinde Antakya Kentsel Alanında Bulunan Belediyelere

Ait Bazı Veriler

\begin{tabular}{|l|l|l|l|}
\hline Adı & Kuruluş Yılı & Mahalle & İl Merkezine Uzaklık \\
\hline Antakya & 1939 & 43 & - \\
\hline Çekmece & 1990 & 4 & 1 \\
\hline Dursunlu & 1994 & 2 & 3 \\
\hline Ekinci & 1994 & 2 & 5 \\
\hline Gümüş̧öze & 1994 & 2 & - \\
\hline Güzelburç & 1994 & 1 & 6 \\
\hline Harbiye & 1939 & 10 & 7 \\
\hline Karaali & 1995 & 2 & 15 \\
\hline Karlısu & 1994 & 2 & 5 \\
\hline Kuzeytepe & 1994 & 2 & 5 \\
\hline Küçükdalyan & 1994 & 1 & 2 \\
\hline Maşuklu & 1994 & 1 & - \\
\hline Narlıca & 1994 & 4 & 2 \\
\hline Odabaşı & 1994 & 2 & 3 \\
\hline Serinyol & 1968 & 4 & 18 \\
\hline Subaşı & 1995 & 1 & 5 \\
\hline Toygarlı & 1994 & 2 & 9 \\
\hline Turunçlu & 1996 & 2 & 6 \\
\hline Yeşilpınar & 1994 & 1 & \\
\hline
\end{tabular}

Kaynak: (Adı̈̈̈zel ve Tek, 2011).

Çizelge 2'de görüleceği gibi, başta Çekmece, Dursunlu, Küçükdalyan, Odabaşı, Turunçlu Beldeleri olmak üzere, Antakya Belediyesi ile sınırdaş olan söz konusu yerleşim birimleri ve belediyeler birbirleriyle iç içe girmiş durumdaydılar. Bu düzenlemeler sonrasında kendi dar sınırlarına hapsedilmiş olan Antakya Belediyesi, kentsel anlamda nefes alamaz duruma getirilmiştir. Daha çok siyasal kaygıların biçimlendirdiği bu çok parçalı yapı, Antakya Belediyesi'nin verimli yerel hizmet sunumunu engellediği gibi, çok önemli tarihi, kültürel, doğal, ekonomik vb. zenginlikleri ile eşsiz bir konuma sahip olan Antakya kentsel alanının ciddi kentsel sorunlarla karşı karşıya kalmasına da neden olmuştur. Belde belediyeleri sahip oldukları yetkilerle, kendi sorumlu oldukları kentsel alanlarda imar ve yapılaşmaya yön vermeye başlamış, ancak 
soyut olarak ellerinde bulunan "yön verme" yetkileri, somut anlamda çağdaş kentin ve kentlinin gereksinimlerini karşılama hedefinin uzağında kalmıştır. Böylelikle, belde belediyeleri kurulurken öngörülmüş olan, "demokratik ve nitelikli kentsel hizmet sunumu” hedeflerine ulaşılamamıştır. Daha sonraki dönemlerde, ortasında sıkışmış Antakya Belediyesi ile birlikte, etrafında kentsel ranta yönelik olarak büyümesini sürdüren 20 'den fazla belde belediyesi, çok parçalı ve bütüncül kentleşme dinamiklerinden yoksun, sorunlu bir “Antakya kentsel alanı”nın oluşmasına neden olmuşlardır.

\section{HATAY'DA BÜYÜKȘEHIR BELEDIYYESİ KURULMASI SÜRECİ}

Çok parçalı ve sorunlu yapısıyla Antakya kentsel alanı için, yapılması gereken en akılcı yönelim, korunması zorunluluk arz edenlerin dışında, küçük belde belediyelerinin en yakın il ve ilçe belediyeleri ile birleştirilmesi olmalıydı. Böylece kentlerin gelişiminde plan bütünlüğünün sağlanması, yerel yönetimin daha etkili ve bütüncül hizmet üretmesi ve başta alt yapı yatırımları olmak üzere, ölçek ekonomilerinden yararlanılarak kaynakların daha akılcı kullanılması sağlanabilirdi. Ancak sorunlu olarak nitelendirdiğimiz Antakya kentsel alanında, var olan çok parçalı ve bizzat kendisi sorun üreten yerel dizgenin değiştirilmesi ya da "Antakya Belediyesi ile birleştirmelerini" de içeren bütüncül bir yapıya dönüştürülmesi, ne özekte bulunan Antakya Belediyesi, ne de çevresinde bulunan belde belediyeleri için bir öncelik oluşturmuştur (Tek, 2009b).Bu sorunlu yerel dizgeden kurtulmanın bir diğer yolu ise Antakya kentsel alanını merkezine alan bir "büyükșehir belediyesi”" kurulmasıydı. Ancak büyükşehir statüsüne kavuşmak 5216 sayılı Yasa hükümleri çerçevesinde zorunlu ve somut bir "nüfus" önkoşuluna bağlanmıştır. Yasanın belirlemiş olduğu 750.000 nüfus ölçütü, Antakya'nın büyükşehir olma sürecini zora sokmuştur. 2011 y1lı genel seçimleri sürecinde gündeme gelen Antakya Büyükşehir Belediyesi tartışmalarının yapıldığı dönemde, Antakya Kenti'nin ve kent özeği ile arasında kentbilim açısından ilişki kurulabilecek yerleşim birimlerinin nüfuslarının toplamı ancak 400.000 civarındaydı ki, bu da büyükşehir kurulabilmesi için gerekli ölçütün çok altında bulunmaktaydı. Bu nedenle de Antakya ve diğer beklenti içerisinde olan orta büyüklükteki kentlerde büyükş̧ehir belediyesi kurulabilmesi için, ya 5216 sayılı Yasa'nın koymuş olduğu nüfus ölçütü aşağıya çekilmeli ya da farklı bir büyükşehir belediyeciliği yaklaşımı ile yeni bir yasal düzenlemeye gidilmeliydi.

2012 yılının sonlarında yürürlüğe giren 6360 sayılı Yasa, farklı bir yaklaşım içerisinde, büyükşehir belediyesi yapısında çok önemli değiş̧iklikler yapmıştır. 6360 sayılı "On Üç İlde Büyükş̧ehir Belediyesi ve Yirmi Altı İlçe Kurulması ile Bazı Kanun ve Kanun Hükmünde Kararnamelerde Değişiklik Yapılmasına Dair Kanun", öncelikle büyükşsehir tanımını değiştirmiştir. Yeni yasaya göre büyükşehir belediyesi, "Sinırları il mülki sınırı olan ve sinırları içerisindeki ilçe belediyeleri arasında koordinasyonu sağlayan; idarî ve malî özerkliğe sahip olarak kanunlarla verilen görev ve sorumluluklar yerine getiren, yetkileri kullanan; karar organı seçmenler tarafindan seçilerek oluşturulan kamu tüzel kişisini" ifade etmektedir. (6360, Madde 4). Görüleceği gibi, yeni tanımlamaya göre, büyükşehir belediyesi sınırları ilin mülki sınırlarını kapsamaktadır. Yeni yasa, "toplam nüfusu 750.000'den fazla olan illerin il belediyeleri yasayla büyükşehir belediyesine dönüştürülebilir” biçimindeki düzenlemesiyle, büyükş̧ehir olma nüfus ölçütünde artık ilin toplam nüfusunun dikkate alınacağını belirtmiştir. İște bu kapsamda kurulmuş olan büyükşehir belediyelerinden birisi de Hatay Büyükşehir Belediyesi'dir.

\section{HATAY'DA BÜYÜKŞEHİR BELEDIYYESİ KURULMASININ GENEL ETKİLERİ}

Hatay'da 6360 sayılı Yasa'nın getirmiş olduğu yeni yapı doğrultusunda büyükşehir belediyesi kurulmasının, il üzerinde çok önemli yönetsel, siyasal, mali ve kentsel etkileri olmuştur.

\subsection{YÖNETSEL YAPIYA ETKILLERI}

2012 yılı Aralık Ayı'nda yürürlüğe giren 6360 sayılı Yasa ileHatay İli'nde, büyükşehir belediyesi kurulması ve sınırlarının ilin mülki sınırı ile örtüştürülmesi, Hatay'ın yerel boyutlarda yönetsel yapısının da değişmesine neden olmuştur. Söz konusu yasa kapsamında, diğer büyükşehir belediyesi kurulan illerde olduğu gibi Hatay İli'nde de il özel idaresi, belde belediyeleri ve köy yönetimlerinin tüzel kişiliklerinin 2014 yılı Mart ayında yapılacak olan yerel seçimlerle birlikte sona ereceği yönünde düzenlemeler yapılmış ve aşağıdaki çizelgeye de yansıdığı gibi, Antakya, Arsuz, Defne ve Payasilçeleri kurulmuştur. Daha önce farklı 
ilçe sınırları içerisinde bulunan bazı belde belediyeleri, köy ve mahalleler, yeni kurulmuş olan bu ilçelere bağlanmıştır. Ayrıca, 1 belde belediyesi ve 7 köy Yayladağı İlçesi'ne, 2 köy de Altınözü İlçesi’ne bağlanmış, bazı ilçelerin sınırlarında da önemli değişiklikler yapılmıştır.

Çizelge 3: Hatay İli’nde Kurulan Yeni İlçeler

\begin{tabular}{|l|l|l|l|}
\hline İlçe & $\begin{array}{l}\text { Bağlanan } \\
\text { Belde } \\
\text { Belediyesi } \\
\text { Sayısı }\end{array}$ & $\begin{array}{l}\text { Bağlanan } \\
\text { Mahalle Sayısı }\end{array}$ & $\begin{array}{l}\text { Bağlanan } \\
\text { Köy } \\
\text { Sayısı }\end{array}$ \\
\hline Antakya & 12 & 41 & 42 \\
\hline Arsuz & 7 & - & 25 \\
\hline Defne & 10 & 4 & 23 \\
\hline Payas & - & - & 3 \\
\hline
\end{tabular}

Kaynak: 6360 sayılı Yasa

6360 sayılı Yasa'nın Hatay İli’nin yerel-yönetsel yapısında ortaya çıkarmış olduğu dönüşümler ile ilgili veriler Çizelge 4'de verilmeye çalışılmıştır.

Çizelge 4: 6360 Sayılı Yasanın Hatay İlindeki Yönetim Birimlerine Etkileri

\begin{tabular}{|c|c|c|c|c|c|c|c|}
\hline \multirow[b]{2}{*}{ Hatay } & \multirow[b]{2}{*}{ İlçe } & \multicolumn{3}{|c|}{ Tüzel Kisiliŏi Kaldırlan } & \multicolumn{3}{|c|}{ Mahalle Sayısı } \\
\hline & & Bucak & Belde & Köy & $\begin{array}{c}\text { 6360 } \\
\text { Öncesi }\end{array}$ & $\begin{array}{c}6360 \\
\text { Sonrası }\end{array}$ & $\begin{array}{c}\text { Yeni } \\
\text { Mahalle } \\
\text { Sayısı }\end{array}$ \\
\hline 1 & Antakva & 5 & 21 & 70 & 43 & 91 & 134 \\
\hline 2 & Altınözü & 3 & 3 & 42 & 2 & 45 & 47 \\
\hline 3 & Belen & - & - & 11 & 6 & 11 & 17 \\
\hline 4 & Dörtvol & 2 & 6 & 6 & 7 & 12 & 19 \\
\hline 5 & Erzin & - & - & 10 & 10 & 10 & 20 \\
\hline 6 & Hassa & 2 & 5 & 28 & 6 & 33 & 39 \\
\hline 7 & İskenderun & 2 & 13 & 37 & 28 & 50 & 78 \\
\hline 8 & Kurukhan & 2 & 1 & 56 & 16 & 57 & 73 \\
\hline 9 & Kumlu & - & - & 13 & 3 & 13 & 16 \\
\hline 10 & Revhanlı & - & - & 31 & 16 & 31 & 47 \\
\hline 11 & Samanda ̌̆ & 2 & 12 & 31 & 9 & 43 & 52 \\
\hline 12 & Yavladă̆ & 3 & 3 & 33 & 3 & 36 & 39 \\
\hline \multicolumn{2}{|c|}{ TOPLAM } & 21 & 64 & 368 & 149 & 432 & 581 \\
\hline
\end{tabular}

Çizelgede de görüleceği gibi, Hatay İli’nde 21 bucak ile 64 belde belediyesive 368 köyün tüzel kişiliği sonlandırılmışıır. 6360 sayılı Yasa öncesinde kentsel alanlarda toplam 149 mahalle bulunurken, 64 belde belediyesi ve 368 köy yönetiminin yasa gereğince mahalleye dönüştürülmesi ile birlikte Hatay İli’nde mahalle sayıs1 581'e ulaşmıştır. 
Yasa gereğince Hatay İli'nde bulunan tüm kamu kurum ve kuruluşlarının yatırım ve hizmetlerinin etkin olarak yapılması, izlenmesi ve koordinasyonu, acil çağnı, afet ve acil yardım hizmetlerinin koordinasyonu ve yürütülmesi, ilin tanıtımı, gerektiğinde merkezi idarenin taşrada yapacağı yatırımların yapılması ve koordine edilmesi, temsil, tören, ödüllendirme ve protokol hizmetlerinin yürütülmesi, ildeki kamu kurum ve kuruluşlarına rehberlik edilmesi ve bunların denetlenmesini gerçekleştirmek üzere Hatay Valiliği’'ne bağlı "Yatırım İzleme ve Koordinasyon Başkanlığı" kurulmuştur. Ayrıca, Hatay İl Özel İdaresi bu yasanın yayım tarihinden itibaren bir ay içerisinde, personel, memur, kadrolu işçi, sözleşmeli çalışanlar, her türlü taşınır ve taşınmazları, hak, alacak ve borçlarını valilikte oluşturulmuş olan Devir Teslim ve Paylaştırma Komisyonu'na bildirmekle zorunlu tutulmuştur. Aynı şekilde belde belediyeleri de yine bu konuda bir ay içerisinde ilçe belediyelerine, ilçe belediyesi henüz kurulmamışsa Hatay Büyükşehir Belediyesi'ne bildirim yapmakla zorunlu tutulmuştur. Ancak vali yardımcısı başkanlığında kurulmuş olan Devir Teslim ve Paylaştırma Komisyonu'nun, bu paylaştırmaları yaparken, büyükşehir belediyesini sürekli olarak ihmal ettiği konusunda iddialar söz konusudur (www.iskenderungazetesi.com).

\subsection{YEREL SIYYASET ÜZERINE ETKILERI}

Hatay İli'nde 6360 sayılı Yasa öncesinde 1'i il merkezinde, 11'i ilçe merkezinde olmak üzere, 64 belde belediyesi ile birlikte toplam 76 belediye bulunmaktaydı. Yeni yasayla Hatay'da bazı ilçelerin sınırları değiştirilerek 4 yeni ilçe kurulmuş, ancak belde belediyeleri kapatılmış olduğundan dolayı belediye sayısı, 1'i büyükş̧ehir ve 15 'i ilçe belediyesi olmak üzere belediye sayısı 16'ya düşmüştür. Hatay İli'nde büyükşehir belediyesi kurulması, kuşkusuz ki ilin siyasal dengelerini de derinden etkilemiştir. Bu siyasal etkiler iki temel perspektif üzerinden değerlendirilebilir. Birincisi, il sınırlarının büyükş̧ehir sınırları, buna paralel olarak da ilçe sınırlarının ilçe belediye sınırları ile eşleştirilmesinin yerel seçim sonuçlarına olası yansımasıdır. İkincisi ise yeni kurulan ilçeler ve buna koşut olarak bazı yerleşim birimleri sınırlarının değiştirilmesinin yaratmış olduğu siyasal sonuçlardır.

Çalı̧̧manın bu bölümünde, öncelikle 2009 Yerel Seçimleri kapsamında Hatay İli, il genel meclisi ve belediye başkanlığı seçim sonuçları verilmiştir. Bu kapsamda, Çizelge 5 ve 6'da görüldüğü gibi, seçimlerde parlamentoda grubu bulunan siyasal partilerin yanı sıra, Hatay İli genelinde, bazı seçim çevrelerinde anlamlı oranlarda oy almış olan siyasal partilerle ilgili seçim sonuçları verilmiştir.

Çizelge 5: 2009 Yerel Seçimlerinde Hatay'da Bazı Siyasal Partilerin İl Genel Meclis Üyeliği Oy Oranları

\begin{tabular}{|l|l|l|l|l|l|l|l|l|l|l|}
\hline \multicolumn{2}{|c|}{ Birimler } & AKP & CHP & MHP & Sa. P. & BBP & DTP & DSP & DP & ÖDP \\
\hline \multirow{4}{*}{ Hata } & Kent & 34,13 & 24,20 & 21,33 & 2,94 & 2,40 & 2,54 & 1,82 & 7,39 & 1,51 \\
\cline { 2 - 10 } & Kir & 30,78 & 29,97 & 18,10 & 2,90 & 1,47 & 0,51 & 6,80 & 5,90 & 0,85 \\
\hline \multirow{4}{*}{ Altınözü } & Kent & 45,82 & 38,42 & 10,45 & 3,19 & 1,00 & 0,00 & 0,24 & 0,27 & 0,00 \\
\hline \multirow{3}{*}{ Antakya } & Kir & 58,69 & 10,71 & 16,36 & 3,34 & 1,10 & 0,00 & 2,45 & 6,52 & 0,00 \\
\hline \multirow{5}{*}{ Belen } & Kent & 45,55 & 32,38 & 11,78 & 1,81 & 4,06 & 0,27 & 1,43 & 0,91 & 0,19 \\
\hline \multirow{3}{*}{ Dörtyol } & Kir & 21,15 & 46,45 & 7,90 & 1,42 & 0,98 & 0,42 & 12,32 & 5,52 & 1,01 \\
\hline & Kent & 40,37 & 9,05 & 44,40 & 4,06 & 1,35 & 0,00 & 0,35 & 0,00 & 0,00 \\
\cline { 2 - 10 } & Kir & 53,87 & 8,64 & 33,48 & 0,79 & 1,67 & 0,00 & 0,59 & 0,00 & 0,00 \\
\cline { 2 - 10 } & Kent & 31,78 & 8,74 & 41,88 & 1,95 & 1,40 & 9,93 & 0,95 & 1,63 & 0,72 \\
\hline
\end{tabular}




\begin{tabular}{|c|c|c|c|c|c|c|c|c|c|c|}
\hline & Kent & 31,97 & 24,38 & 20,92 & 1,27 & 1,32 & 12,76 & 0,48 & 5,85 & 0,10 \\
\hline Erzin & Kir & 40,22 & 15,87 & 34,10 & 2,98 & 2,26 & 0,24 & 0,33 & 3,40 & 0,09 \\
\hline \multirow{2}{*}{ Hassa } & Kent & 29,38 & 17,73 & 28,45 & 16,66 & 0,92 & 0,00 & 0,50 & 5,73 & 0,00 \\
\hline & Kir & 48,02 & 4,16 & 34,28 & 9,17 & 1,30 & 0,00 & 0,30 & 1,94 & 0,00 \\
\hline \multirow{2}{*}{ İskenderun } & Kent & 26,59 & 32,43 & 15,54 & 1,30 & 2,09 & 3,27 & 1,06 & 15,67 & 0,21 \\
\hline & Kir & 26,97 & 31,12 & 16,83 & 2,62 & 3,18 & 0,55 & 3,31 & 8,77 & 0,18 \\
\hline \multirow{2}{*}{ Kırıkhan } & Kent & 32,23 & 4,63 & 36,51 & 3,70 & 0,86 & 0,00 & 0,70 & 20,73 & 0,10 \\
\hline & Kir & 42,09 & 5,24 & 28,27 & 4,95 & 1,25 & 0,00 & 1,01 & 16,41 & 0,14 \\
\hline \multirow{2}{*}{ Kumlu } & Kent & 27,87 & 12,56 & 24,22 & 0,45 & 9,72 & 0,00 & 17,21 & 7,41 & 0,00 \\
\hline & Kir & 48,15 & 9,33 & 22,10 & 3,47 & 4,65 & 0,00 & 4,11 & 7,17 & 0,00 \\
\hline \multirow[b]{2}{*}{ Reyhanlı } & Kent & 40,45 & 7,63 & 32,86 & 14,07 & 3,53 & 0,00 & 0,00 & 0,54 & 0,00 \\
\hline & Kir & 51,17 & 10,61 & 18,85 & 13,78 & 2,20 & 0,00 & 0,00 & 1,60 & 0,00 \\
\hline \multirow[b]{2}{*}{ Samandağ } & Kent & 10,69 & 39,15 & 2,19 & 0,12 & 0,32 & 0,00 & 13,26 & 5,02 & 21,67 \\
\hline & Kir & 13,84 & 50,21 & 9,50 & 0,30 & 0,42 & 0,03 & 16,51 & 2,77 & 4,26 \\
\hline \multirow[b]{2}{*}{ Yayladağı } & Kent & 44,63 & 6,57 & 42,83 & 0,90 & 0,50 & 0,00 & 1,03 & 2,21 & 0,00 \\
\hline & Kir & 54,63 & 17,32 & 16,84 & 2,75 & 1,93 & 0,00 & 2,14 & 2,52 & 0,00 \\
\hline
\end{tabular}

Kaynak: TUIK, 2013

Yukarıdaki çizelgeye oranları yansıtıldığı gibi, 2009 yılında yapılmış olan yerel seçim sonuçlarına göre, Hatay'da ilçe merkezlerinde daha çok büyük siyasal partiler başarılı olurken, küçük siyasal partiler ancak bazı belde belediyelerini kazanabilmişlerdir.

Çizelge 6: 2009 Yerel Seçimlerinde Hatay'da Bazı Siyasal Partilerin Belediye Başkanlığı Seçimi Oy Oranları

\begin{tabular}{|l|l|l|l|l|l|l|l|l|l|l|l|l|l|l|l|}
\hline Birim & AK & CH & MH & Sa. & DS & DP & ÖD & Birim & AK & CH & MH & Sa. & DS & DP & ÖD \\
\hline TÜRKIYY & 38,6 & 24,6 & 16,4 & 5,39 & 2,87 & 3,62 & 0,1 & Ardıçlı & 42,9 & 0,00 & 55,6 & 1,44 & 0,00 & 0,00 & 0,0 \\
\hline Hatay & 29,4 & 26,7 & 19,3 & 2,27 & 6,16 & 9,85 & 1,7 & Söğ̈̈t & 37,4 & 0,00 & 60,9 & 1,63 & 0,00 & 0,00 & 0,0 \\
\hline Altınözü & 49,7 & 47,3 & 1,33 & 0,65 & 0,00 & 0,27 & 0,0 & Aktepe & 52,1 & 0,00 & 45,7 & 2,02 & 0,00 & 0,00 & 0,0 \\
\hline Altınkaya & 48,0 & 0,00 & 50,6 & 1,31 & 0,00 & 0,00 & 0,0 & Küreci & 56,8 & 0,00 & 39,1 & 4,07 & 0,00 & 0,00 & 0,0 \\
\hline Hacıpaşa & 44,2 & 0,00 & 0,00 & 0,87 & 0,00 & 54,8 & 0,0 & İskenderu & 26,1 & 32,9 & 12,7 & 0,71 & 0,00 & 24,5 & 0,0 \\
\hline Karbeyaz & 29,0 & 31,2 & 2,02 & 0,26 & 9,93 & 27,5 & 0,0 & Azganlık & 53,6 & 0,00 & 45,9 & 0,45 & 0,00 & 0,00 & 0,0 \\
\hline Ant./Mer & 48,3 & 36,2 & 9,10 & 1,26 & 0,59 & 0,27 & 0,4 & Bekbele & 31,0 & 0,00 & 28,1 & 18,1 & 0,00 & 0,00 & 0,0 \\
\hline Avsuyu & 37,9 & 0,13 & 0,00 & 0,17 & 0,00 & 37,6 & 0,0 & Denizciler & 46,6 & 0,00 & 25,3 & 1,41 & 0,00 & 23,5 & 0,0 \\
\hline
\end{tabular}




\begin{tabular}{|c|c|c|c|c|c|c|c|c|c|c|c|c|c|c|c|}
\hline Dursunlu & 0,14 & 61,7 & 0,00 & 0,06 & 29,5 & 0,00 & 8,4 & Karaağaç & 0,57 & 52,9 & 0,38 & 0,13 & 5,96 & 0,00 & 0,0 \\
\hline Küçükdal & 1,69 & 31,0 & 0,19 & 0,17 & 20,0 & 8,18 & 0,0 & Karayılan & 13,3 & 9,27 & 38,9 & 1,11 & 1,96 & 2,22 & 0,0 \\
\hline Maşuklu & 2,66 & 53,9 & 0,00 & 0,18 & 43,2 & 0,00 & 0,0 & Nardüzü & 0,19 & 50,3 & 0,19 & 0,00 & 23,8 & 25,3 & 0,0 \\
\hline Narlica & 69,6 & 0,00 & 26,7 & 3,57 & 0,00 & 0,00 & 0,0 & Sarıseki & 21,0 & 5,93 & 14,3 & 6,94 & 0,00 & 16,1 & 0,0 \\
\hline Harbiye & 0,34 & 56,9 & 0,00 & 0,16 & 0,00 & 42,1 & 0,0 & Arsuz & 40,1 & 50,1 & 1,11 & 0,07 & 0,00 & 8,44 & 0,0 \\
\hline Gümüşgöz & 0,07 & 47,4 & 0,00 & 0,07 & 32,6 & 19,8 & 0,0 & & 0,12 & 47,2 & 0,24 & 0,08 & 9,97 & 42,3 & 0,0 \\
\hline Yeşilpınar & 0,00 & 39,8 & 0,00 & 0,04 & 36,0 & 24,1 & 0,0 & Gökmeyda & 0,00 & 37,4 & 0,18 & 0,00 & 8,08 & 48,1 & 0,0 \\
\hline Çekmece & 1,67 & 41,0 & 1,89 & 0,14 & 51,3 & 3,86 & 0,0 & Gözcüler & 0,38 & 54,1 & 0,23 & 0,05 & 6,37 & 38,8 & 0,0 \\
\hline Ekinci & 0,03 & 52,6 & 0,00 & 0,00 & 40,8 & 0,00 & 6,4 & Madenli & 4,21 & 67,6 & 0,32 & 0,04 & 0,00 & 27,8 & 0,0 \\
\hline Güzelburç & 7,18 & 50,7 & 0,00 & 0,30 & 0,00 & 41,7 & 0,0 & & 0,51 & 87,7 & 0,79 & 0,09 & 2,89 & 7,98 & 0,0 \\
\hline Karlisu & 41,2 & 52,9 & 0,00 & 5,74 & 0,00 & 0,00 & 0,0 & Kırıkhan & 23,8 & 1,46 & 41,4 & 2,99 & 0,89 & 29,0 & 0,0 \\
\hline Kuzeytepe & 0,16 & 29,4 & 0,00 & 0,13 & 48,2 & 0,00 & 21, & Kurtlusoğu & 45,1 & 0,00 & 54,7 & 0,13 & 0,00 & 0,00 & 0,0 \\
\hline Odabaşı & 13,7 & 38,8 & 2,81 & 0,88 & 40,7 & 0,00 & 0,0 & Kumlu & 37,4 & 0,00 & 38,1 & 0,20 & 24,1 & 0,00 & 0,0 \\
\hline Subaşı & 12,0 & 87,5 & 0,00 & 0,43 & 0,00 & 0,00 & 0,0 & Reyhanlı & 42,4 & 6,46 & 36,3 & 14,4 & 0,00 & 0,00 & 0,0 \\
\hline & 0,00 & 59,3 & 0,00 & 0,43 & 40,2 & 0,00 & 0,0 & nandağ & 13,5 & 32.2 & 0,00 & 0,46 & 19,2 & 0,00 & 34, \\
\hline Turunçlu & 0,29 & 61,9 & 0,00 & 0,29 & 37,5 & 0,00 & 0,0 & Aknehir & 0,07 & 33,9 & 0,00 & 0,00 & 19,8 & 0,00 & 46 , \\
\hline Serinyol & 8,61 & 42,9 & 0,00 & 0,07 & 47,8 & 0,37 & 0,0 & Koyunoğlu & 0,00 & 51,2 & 0,00 & 0,04 & 48,7 & 0,00 & 0,0 \\
\hline Karaali & 26,2 & 28,1 & 0,00 & 0,06 & 32,3 & 9,02 & 4,2 & Kuşalanı & 0,30 & 94,8 & 0,00 & 4,82 & 0,00 & 0,00 & 0,0 \\
\hline Ovakent & 30,1 & 0,55 & 60,1 & 0,78 & 0,00 & 0,00 & 0,0 & Mağaracık & 28,1 & 58,3 & 0,00 & 0,04 & 13,4 & 0,00 & 0,0 \\
\hline Şenköy & 76,6 & 2,02 & 0,00 & 1,84 & 0,00 & 0,00 & 0,0 & Mizrakli & 0,21 & 55,1 & 0,00 & 0,25 & 43,3 & 1,07 & 0,0 \\
\hline Belen & 40,2 & 6,80 & 49,4 & 3,29 & 0,00 & 0,00 & 0,0 & Sutaş1 & 37,1 & 58,6 & 0,00 & 0,42 & 3,73 & 0,00 & 0,0 \\
\hline Dörtyol & 35,3 & 5,45 & 46,4 & 1,18 & 0,30 & 0,65 & 0,0 & Tekebaşı & 42,2 & 39,7 & 0,00 & 0,28 & 13,0 & 4,69 & 0,0 \\
\hline Altınçăg & 28,1 & 21,7 & 22,7 & 1,10 & 0,00 & 26,3 & 0,0 & Değirmenb & 0,00 & 50,6 & 0,00 & 0,17 & 49,2 & 0,00 & 0,0 \\
\hline Karakese & 43,5 & 0,00 & 51,5 & 1,16 & 0,00 & 0,90 & 0,0 & & 0,00 & 50,9 & 0,00 & 0,05 & 47,0 & 0,00 & 1,9 \\
\hline Kuzuculu & 40,7 & 9,39 & 48,7 & 0,43 & 0,00 & 0,00 & 0,0 & Tomruksuy & 0,06 & 42.1 & 0,00 & 0,00 & 15,1 & 0,00 & 31 , \\
\hline Yeniyurt & 33,9 & 0,29 & 29,6 & 0,22 & 0,00 & 35,9 & 0,0 & Uzunbağ & 0,00 & 54,8 & 0,00 & 0,22 & 44,1 & 0,00 & 0,0 \\
\hline Yeşilköy & 37,2 & 21,7 & 36,7 & 1,07 & 0,00 & 0,00 & 0,0 & Yaylica & 2,44 & 29,4 & 0,00 & 0,05 & 62,3 & 5,77 & 0,0 \\
\hline Payas & 31,1 & 9,87 & 54,2 & 2,25 & 0,00 & 0,74 & 0,0 & Yayladağı & 45,9 & 0,00 & 50,5 & 0,63 & 1,54 & 1,19 & 0,0 \\
\hline & 35,9 & 25,2 & 16,9 & 0,56 & 0,15 & 7,29 & 0,0 & Kişlak & 52,0 & 40,9 & 5,79 & 1,21 & 0,00 & 0,00 & 0,0 \\
\hline Hassa & 23,8 & 17,1 & 28,7 & 22,7 & 0,00 & 7,31 & 0,0 & Yeditepe & 56,3 & 0,00 & 43,2 & 0,32 & 0,00 & 0,00 & 0,0 \\
\hline Akbez & 43,1 & 0,00 & 26,0 & 30,7 & 0,00 & 0,00 & 0,0 & Karaköse & 24,0 & 0,00 & 28,4 & 0,00 & 0,00 & 21,7 & 0,0 \\
\hline
\end{tabular}

Kaynak: (TUİK, 2013) verileri kullanılarak hazırlanmıştır. 
2009 yılında yapılmış olan belediye başkanlığı seçim sonuçlarının yansıtıldığı Çizelge 7'de görüldüğü gibi,CHP 1'i ilçe belediyesi olmak üzere toplamda 29 belediye başkanlığı, AKP 4'ü ilçe olmak üzere 18 belediye başkanlığı, MHP ise 6'sı ilçe olmak üzere toplam 16 belediye başkanlığı kazanmıştır. Ayrıca seçim sonuçlarına göre DSP'nin 6, DP'nin 3, ANAP'1n 2 belde belediye başkanlığ 1 , ÖDP'nin ise 1'i ilçe olmak üzere 2 belediye başkanlığı kazanmış olduğu görülmektedir.

Çizelge 7: 2009 Yerel Seçimleri'nde Hatay İl'inde Belediye Başkanlığı Kazanan Partiler ve Belediye Başkanlığı Sayıları

\begin{tabular}{|l|l|l|l|l|l|l|l|}
\hline & CHP & AKP & MHP & DSP & DP & ANAP & ÖDP \\
\hline İlçe Belediyesi & 1 & 4 & 6 & - & - & - & 1 \\
\hline Belde Belediyesi & 28 & 14 & 10 & 6 & 3 & 2 & 1 \\
\hline TOPLAM & 29 & 18 & 16 & 6 & 3 & 2 & 2 \\
\hline
\end{tabular}

2009 Yerel Seçimleri verileriyle, 2014 Yerel Seçimleri sonuçlarını karşılaştırabilmek için, Çizelge 8'de 2104 Yerel Seçimleri'nde Hatay İli'nde siyasal partilerin BŞB ve ilçe belediye başkanlığı, Çizelge 9'da ise $\mathrm{BSSB}$ ve ilçe belediye meclisi seçimlerinde almış oldukları sonuçlar verilmiştir.

Çizelge 8: Hatay İli’nde, 2014 Yerel Seçimlerinde Bazı Siyasal Partilerin BŞB ve İlçe Belediye Başkanlığı Seçimleri Oy Oranları

\begin{tabular}{|l|l|l|l|l|l|l|l|}
\hline Birimler & AKP & CHP & MHP & Saadet P. & BBP & HDP & Diğer \\
\hline Hatay BŞB & $\mathbf{4 0 . 4}$ & $\mathbf{4 0 . 8}$ & $\mathbf{1 5 . 4}$ & $\mathbf{0 . 9}$ & $\mathbf{0 . 2}$ & $\mathbf{1 . 3}$ & IPP/0.01 \\
\hline Altı̈özü & $\mathbf{6 2 . 0}$ & 12.0 & 23.2 & 1.3 & 1.9 & - & - \\
\hline Antakya & $\mathbf{5 2 . 0}$ & 33.0 & 12.6 & 0.7 & 0.2 & 0.2 & - \\
\hline Arsuz & 17.4 & $\mathbf{6 5 . 1}$ & 10.4 & 0.1 & - & - & ÖDP/2.8 \\
\hline Belen & $\mathbf{4 8 . 4}$ & 6.4 & 43.6 & 0.9 & 0.3 & - & - \\
\hline Defne & 3.3 & $\mathbf{8 2 . 0}$ & 0.7 & - & - & 0.8 & TKP/7.6 \\
\hline Dörtyol & 37.5 & 15.8 & $\mathbf{3 9 . 4}$ & 0.9 & 0.3 & 5.3 & - \\
\hline Erzin & $\mathbf{3 8 . 2}$ & 24.8 & 27.5 & 0.8 & - & 7.4 & - \\
\hline Hassa & $\mathbf{5 2 . 5}$ & 1.3 & 43.3 & 1.7 & 0.4 & - & - \\
\hline İskenderun & $\mathbf{3 7 . 5}$ & 35.3 & 23.0 & 0.6 & 0.4 & 1.9 & - \\
\hline Kirıkhan & $\mathbf{6 5 . 0}$ & 3.1 & 28.4 & 2.6 & 0.3 & - & - \\
\hline Kumlu & $\mathbf{4 1 . 9}$ & 20.3 & 37.7 & - & - & - & - \\
\hline Payas & $\mathbf{4 6 . 6}$ & 5.5 & 13.5 & 32.4 & 0.1 & 1.3 & - \\
\hline
\end{tabular}

- Yüksek Seçim Kurulu 2014 Yerel Seçimleri ile ilgili olarak tüm resmi sonuçları yayımlamadığı için, bu iki çizelge, farklı yayın organlarından karşılaştırma yapmak suretiyle oluşturulmuştur. 


\begin{tabular}{|l|l|l|l|l|l|l|l|}
\hline Reyhanlı & $\mathbf{5 4 . 6}$ & 14.6 & 29.1 & 1.0 & 0.4 & - & - \\
\hline Samandağ 1 & 4.9 & $\mathbf{8 1 . 6}$ & 1.6 & 0.1 & - & 1.1 & IPP/9.8 \\
\hline Yayladağ 1 & $\mathbf{6 0 . 0}$ & - & 38.7 & 0.8 & 0.1 & - & - \\
\hline
\end{tabular}

Kaynak:( http://www.bugun.com.tr/); (http://www.cnnturk.com/).

Daha önce yapılmış olan bir çalışmada (Adıgüzel, Tek, 2014),2014 yılı Mart ayında yapılacak olan yerel seçimlerde, seçim sonuçlarını etkileyecek çok farklı değişkenlerin olabileceğine vurgu yapılmıştır. Örneğin partilerin bir seçim çevresinde il genel meclisi seçimlerinde almış oldukları oy oranlarının, aynı seçim çevresindeki belediye seçimlerinde önemli oranlarda değişmesine neden olabilecek, başta belediye başkan adaylarının özellikleriyle ilgili olmak üzere bir takım yerel etkenlerin ortaya çıkabileceğine dikkat çekilmiştir. Ayrıca, 6360 sayılı Yasa kapsamında Hatay İli'nde yeni ilçeler kurulurken, bu ilçelerin sınırlarının tespitine yönelik olarak, Hatay yerelinde farklı tepkilerin ortaya çıkmış olduğu, diğer yandan Suriye'de yaşanmakta olan iç savaş ortamının Türkiye'ye yansımalarının coğrafi konumu nedeniyle Hatay'da çok daha farklı hissedildiği, dolayısıyla da bu gelişmelerin ildeki yerel seçimleridaha fazla etkileyebileceği vurgusu yapılmıştır. Bu yerel etkilerin yanı sıra, genel ülke siyaseti ile ilgili olarak 2013 yılı Aralık ayında ortaya çıkan gelişmelerin ve bu gelişmelerin yaratmış olduğu siyasal gerilim ve kutuplaşma ortamının, yerel seçim yarışının genel seçim atmosferine dönüşmesine neden olduğuna ve bu gelişmelerin, 30 Mart'dayapılacak olan yerel seçimlerde tüm ülkeyi etkileyeceği gibi, Hatay yerelini de derinden etkileyeceğine dikkat çekilmiştir. Sonrasında, çalışmada tüm bu etkileri de göz önünde bulundurarak, Hatay'da 2014 Yerel Seçimleri'nde siyasal partilerin alabileceği olası sonuçlar üzerinde değerlendirmelere yer verilmiştir.

Çizelge 9: Hatay İli’nde, 2014 Yerel Seçimlerinde Bazı Siyasal Partilerin

\section{Belediye Meclisi Seçimleri Oy Oranları}

\begin{tabular}{|l|l|l|l|l|l|l|l|}
\hline Birimler & AKP & CHP & MHP & $\begin{array}{l}\text { Sa. } \\
\text { P. }\end{array}$ & BBP & HDP & Diğer \\
\hline Hatay BŞB & $\mathbf{3 7 . 7}$ & $\mathbf{3 6 . 0}$ & $\mathbf{1 9 . 3}$ & $\mathbf{1 . 5}$ & $\mathbf{0 . 5}$ & $\mathbf{1 . 4}$ & IP/1.3 \\
\hline Altınözü & 62.8 & 12.0 & 21.6 & 1.1 & 1.9 & - & - \\
\hline Antakya & 47.8 & 38.1 & 12.4 & 0.8 & 0.4 & 0.2 & $\begin{array}{l}\text { ÖDP/2 } \\
.8\end{array}$ \\
\hline Arsuz & 17.8 & 64.0 & 10.6 & 0.1 & - & - & $\begin{array}{l}\text { DSP/3. } \\
5\end{array}$ \\
\hline Belen & 49.1 & 8.5 & 40.4 & 1.2 & 0.4 & - & - \\
\hline Defne & 3.3 & 82.0 & 0.7 & - & - & 0.8 & $\begin{array}{l}\text { TKP/7 } \\
.6\end{array}$ \\
\hline Dörtyol & 37.0 & 16.8 & 38.3 & 1.1 & 0.6 & 4.7 & - \\
\hline Erzin & 35.6 & 24.8 & 29.3 & 0.8 & 0.3 & 8.2 & - \\
\hline Hassa & 54.1 & 3.1 & 38.8 & 2.1 & 0.9 & - & - \\
\hline İskenderun & 36.9 & 33.8 & 23.2 & 1.1 & 0.9 & 1.9 & - \\
\hline Kırikhan & 62.9 & 6.3 & 26.1 & 2.5 & 0.5 & - & - \\
\hline Kumlu & 38.5 & 21.8 & 36.1 & 1.7 & 1.6 & - & - \\
\hline Payas & 48.5 & 8.6 & 15.7 & 22.8 & 0.3 & 2.4 & - \\
\hline
\end{tabular}




\begin{tabular}{|l|l|l|l|l|l|l|l|}
\hline Reyhanl1 & 52.7 & 17.4 & 27.6 & 1.2 & 0.7 & - & - \\
\hline Samandağ1 & 5.1 & 75.9 & 2.8 & 0.08 & - & 3.2 & $\begin{array}{l}\text { İP/11. } \\
0\end{array}$ \\
\hline Yayladağ1 & 61.7 & - & 36.6 & 0.8 & 0.2 & - & - \\
\hline
\end{tabular}

Kaynak:( http://www.bugun.com.tr/); (http://www.cnnturk.com/).

Yukarıda gönderme yapılan çalışmada altı çizilen, tüm bu yerel ve genel boyutları olan farklı değişkenler ve duyarlılıkların, 30 Mart 2014 tarihinde yapılmış olan yerel seçimlerde, sonuçlar üzerinde önemli etkilerinin olduğu gözlenmiştir. 6360 sayılı Yasa'nın Hatay İli'nde ortaya çıkarmış olduğu yeni yerel yapının, 2014 Yerel Seçimleri üzerindeki etkilerini, 2009 yılında yapılmış olan yerel seçim sonuçları da göz önünde bulundurmak suretiyle, karş1laştırma yaparak özetlemek mümkündür:

- 2014 Yerel Seçim sonuçları göstermiş̧tir ki, 6360 sayılı Yasaile ortaya çıkan yeni büyükşehir belediyesi dizgesi, parlamento dışında kalmış küçük siyasal partilerin aleyhine bir siyasal durum yaratmıştır. Bu durum, tüm Türkiye'de olduğu gibi, Hatay İli seçim çevresinde de somut olarak ortaya çıkmıştır. 2009 Yerel Seçimleri'nde, Çizelge 7'de de görüleceği gibi, CHP biri ilçe olmak üzere toplamda 29 belediye başkanlığı, AKP dördü ilçe olmak üzere 18 belediye başkanlığı, MHP altısı ilçe olmak üzere 16 belediye başkanlığı, ayrıca DSP 6, DP 3, ANAP 2 belde belediye başkanlığı, ÖDP ise biri ilçe olmak üzere 2 belediye başkanlığı kazanmışlardır.Bu seçim sonuçlarına göre, günümüzde parlamentoda temsil edilemeyen küçük siyasal partiler, Hatay'da biri ilçe olmak üzere toplam 13 belediye başkanlığı kazanma başarısı göstermişlerdir. 6360 sayılı Yasa ile belde belediyelerinin kapatılmış olması, küçük siyasal partilerin aleyhine yeni siyasal sonuçların ortaya çıkmasına neden olmuştur. Belediye başkanlığı seçimlerinde seçmenler genellikle stratejik oy verme eğilimi içerisinde hareket etmişlerdir. Bu nedenle de 2014 Yerel Seçimlerinde, küçük siyasal partiler Hatay İ'i genelinde her hangi bir ilçe belediye başkanlığı kazanma başarısı gösterememişlerdir. Dolayısıyla Hatay İli'nde küçük siyasal partilerin il genelinde daha önceleri yakalamış oldukları görece başarılı performans, 2014 seçimlerinde sona ermiştir.

- Parlamentoda üçüncü büyük siyasal parti olan MHP, gerek daha önce başarılı olduğu ilçelerin sınırlarının değiştirilmesi, gerekse yeni yapının daha güçlü siyasal partileri öne çıkarması nedeniyleHatay'da önceki başarısını yakalayamamıştır. MHP'li seçmenlerin bir kısmının "stratejik oy" kullanma eğilimi içerisinde oy vermeleri sonucunda, MHP önceki seçimlerde almış olduğu oy oranlarını korumasına rağmen yalnızca Dörtyol İlçe Belediye Başkanlığı'nı kazanabilmiştir.MHP 2009 yerel seçimlerinde Hatay'da 6 ilçe belediye başkanlığı kazanmış olmasına rağmen, Çizelge 5 ve 6 'da da görüleceği gibi, MHP'nin ilçe merkezlerindeki güçlü konumunun, 6360 sayılı Yasa doğrultusunda seçim çevresinin ilçenin tüm mülki sınırı ile örtüştürülmüş olması nedeniyle sarsılabileceği öngörülmüştür. Çünkü MHP'nin belediye başkanlığ1 kazanmış olduğu ilçelerin genelinde kır oyları AKP'ye göre daha düşüktür ve ilçe belediye başkanlığı seçimlerine kır seçmeni eklendiğinde, bu ilçelerde ciddi bir MHP-AKP rekabeti söz konusu olacağ 1 bilinmekteydi. Özellikle Yayladağı, Kumlu, Hassa ve Kırıkhan ilçelerinde belediye başkanlıklarını AKP'nin kazanma olasılığının yüksek olduğu tahmin edilmekteydi. MHP'nin başarılı olduğu diğer bir ilçe olan Dörtyol'da ise ilçenin sınırları içerisinde Payas İlçesi'nin kurulmuş olması, Dörtyol ilçe belediyesinin de kaybedilme riskini berberinde getirmiştir. 6360 sayılı Yasa'nın Hatay İli’nde ortaya çıkarmış olduğu yeni yerel dizge 2014 Yerel Seçimleri'nde MHP'yi derinden etkilemiştir. MHP 2009 seçimlerindeki oy oranlarını tekrar yakalamasına rağmen, sahip olduğu 6 ilçe belediye başkanlığından Dörtyol İlçesi dışında tümünü AKP'ye kaptırmıştır.

- Bu yeni dizgenin CHP üzerinde de belirgin etkileri olmuştur. 2009 yerel seçim sonuçlarını yansıtan Çizelge 5 ve 6'da görüleceği gibi, Hatay'ın belli kırsal alanlarında CHP güçlü bir siyasal partidir ve il genel meclisi seçim sonuçlarına göre CHP özellikle Antakya ve İskenderun ilçelerinde güçlü bir konuma sahiptir. Yukarıda da vurgulamış olduğumuz bir çalışmada (Adıgüzel, Tek, 2014, ), 6360 sayılı Yasa kapsamında, bu ilçeler içerisinde tartışmalı sınırları ile yeni ilçelerin kurulmuş olmasının farklı yeni siyasal sonuçların ortaya çıkmasına neden olabileceğine vurgu yapılmıştır. Bu nedenle de, 2014 Yerel Seçimleri'nde CHP'nin, yalnızca yeni kurulmuş olan küçük ilçelerde güçlü konumunu devam ettirebileceği iddia edilmişti. Gerçekten de sınır değişikliği sonucunda ortaya çıkan yeni yerel yapı, CHP'nin, Antakya ve İskenderun gibi çok önemli 
ilçelerin belediye başkanlıklarını kazanma konusundaki güçlü konumunu derinden sarsmıştır. CHP söz konusu iki büyük ilçede de belediye başkanlığını AKP'ye kaptırmış, yalnızca bu iki ilçeden ayrılarak kurulmuş olan Defne ve Arsuz belediye başkanlıklarını kazanabilmiştir. Bunun yanı sıra CHP, seçimlerde sürekli olarak sol adayların kazanmakta olduğu Samandağ Belediye Başkanlıkları'nı kazanabilmiştir.

CHP, 2009 yerel seçim il genel meclisi sonuçlarını yansıtan Çizelge 5'de görüleceği gibi, Hatay İli genelinde birkaç puan oy farkıyla AKP'nin gerisinde olmakla birlikte, 2014 Yerel Seçimleri'nde büyükşehir belediye başkanlığı seçimlerini kıl payı farkla da olsa kazanmıştır. CHP'nin bu başarısının en önemli nedenlerinden birisi, belki de en önemlisi aday gösterme konusunda tutunduğu tavırdır. CHP, Suriye'de yaşanmakta olan gelişmelerin Hatay'a olan yansımalarını doğru okuyarak, kentte yaşanmakta olan mezhepsel gerginliği azaltacağı ve daha kucaklayıcı olacağını düşündügü̈ Antakya eski Belediye Başkanı Lütfü Savaş'ı aday göstermiş̧ir. CHP, Lütfü Savaş'ın hem sağ, hem de sol seçmenden oy alabileceğini hesaplamış, nitekim bu hesabı da doğru çıkmıştır. Çizelge 8 ve 9'da görüldüğü gibi, Lütfü Savaş özellikle MHP'li seçmen tarafindan da tercih edilmiştir. MHP, büyükşehir belediye meclisi seçimlerinde \%19.3 oranında oy alırken, büyükşehir belediye başkanlığı seçimlerinde MHP adayı \%15.4 oranında oy alabilmiştir. $\mathrm{Bu}$ da göstermiştir ki MHP'li seçmenlerin bir kısmı büyükşehir belediye başkanlığı seçimlerinde "stratejik oy" verme eğilimi içerisine girmiş ve CHP'li adayı kendisine yakın görerek desteklemiştir. CHP ise büyükşehir belediye meclisi seçimlerinde \%36 oranında oy alırken, büyükşehir belediyesi başkan adayı $\% 40.8$ oranında oy alarak AKP adayının önüne geçmiştir.

- 6360 sayılı Yasa'nın oluşturduğu yeni yerel dizge, daha çok büyük partilere yaramış ve kuşkusuz ki en fazla da AKP'yi olumlu yönde etkilemiştir. AKP, Türkiye'nin her bölgesinde yüksek oranlarda oy potansiyellerine sahiptir. Ancak AKP'nin kırsal alanlarda daha güçlü olduğu da bir gerçektir. Bu nedenle AKP, yeni büyükşehir belediyesi sisteminden dolayı, diğer büyükşehir belediyelerinde olduğu gibi Hatay'da da güçlü bir konum elde etmiştir. Ayrıca, yeni ilçeler kurulurken ve yeni seçim çevreleri oluşturulurken, AKP'nin diğer siyasal partilere göre daha avantajlı çıkmasını sağlayıcı yönde sınır kaydırmaları ve planlamaları yapıldığı kuşkusu da söz konusudur. Bu durum da göz önünde bulundurulduğunda AKP Hatay İli'nde başarılı olmuş, 2009 Yerel Seçimleri'ne göre oy oranlarını arttırmış, 4 olan ilçe belediye başkanlıklarını 11'e yükseltmiş, ancak Hatay Büyükşehir Belediye Başkanlığını kıl payı CHP'ye kaptırmıştır. AKP'nin bu başarısının önemli nedenlerinden birisi yeni büyükşehir belediyesi dizgesidir. Antakya ve İskenderun İlçeleri'nin bölünerek, bu ilçeler içerisinde sınırları tartışma yaratmış yeni ilçelerin kurulması, AKP'nin bu iki büyük ilçeyi daha kolay bir şekilde kazanmasına katkı yapmıştır.

- 6360 sayılı Yasa'nın ortaya çıkarmış olduğu yeni yerel dizge, 2014 Yerel Seçimleri'nde Hatay Büyükşehir Belediyesi Meclisi'nde "sorunlu" bir meclis yapısının ortaya çıkmasına neden olmuştur. Çizelge 9'da görüleceği gibi, büyükşehir belediye meclisi seçim sonuçlarına göre, birinci olan AKP \% 37.7, ikinci olan CHP ise \% 36 oranında oy almışken, Hatay Büyükşehir Belediyesi Meclisi'nde 50 AKP'li, 25 CHP'li, 11 MHP'li ve 1 Saadet Partili üye bulunmaktadır. Büyükşehir belediye başkanın CHP'de, meclis üye çoğunluğunun ise AKP'de olması, aslında uzlaşma, hoşgörü ve birlikte yaşama kavramalarıyla özdeşleşmiş Hatay için bir şans olması ve bu yeni durumu "uzlaşma kültürü" adına firsata dönüştürmek gerekirken, daha ilk meclis toplantısında bu olumlu beklentilerin gerçekleşmesinin çok zor olacağına dair ipuçları ortaya çıkmıştır.

\subsection{MALI YAPIYA ETKILERI}

6360 sayılı Yasa öncesinde Antakya kentsel alanında yirmiye yakın belediye hizmet sunmaktayken, bu alanın merkezinde $22.5 \mathrm{~km}$. karelik alana da Antakya Belediyesi hizmet vermekteydi. Antakya Belediyesi, bu alanda bulunan 220.000'den fazla bir nüfusa, yıllık ortalama 134 milyon liralık bütçeyle hizmet sunmaya çalışmaktaydı. Hatay Büyükşehir Belediyesi'nin 2014 Mart ayında yapılmış olan yerel seçimler sonrasında fiilen göreve başlamasıyla birlikte, hizmet götürmeye çalıştığı alan $5867 \mathrm{~km}$. kareye, nüfus ise 1 milyon 500 bine ulaşmıştır. Hatay Büyükşehir Belediyesi'nin göreve başlaması ile birlikte hem büyükşsehir belediyesi, hem de büyükşehirdeki ilçe belediyelerinin çok daha fazla mali imkanlara kavuşmuş olduklarını söylemek mümkündür. Ancak bu artışlarla ilgili çok farklı rakamlar söz konusudur (TEPAV, 2012; TEPAV, 2013; Y1ld1z, 2013; AKP, 2012). 
6360 sayılı Yasa'nın 25 ve 26. Maddelerinde yapılan düzenlemeyle, “Özel Tüketim Vergisi Kanunu'na ekli (I) sayll listede yer alan mallardan tahsil edilen özel tüketim vergisi hariç olmak üzere, büyükşehir belediye sınırları içinde yapılan genel bütçe vergi gelirleri tahsilatı toplamının \% 6'sı büyükşehir belediye payı olarak ayrılacaktır. Söz konusu \% 6'lık payın \% 60'1 doğrudan büyükşehir belediyesine aktarılırken,\% 6'lık dilimin kalan \% 40'1 diğer büyükşsehir belediyelerinden aktarılan \% 40'larla bir havuzda toplanacak ve bu havuzda biriken kaynağın \% 70'i büyükşehir belediyelerinin nüfuslarına göre, \% 30'u ise yüzölçümlerine göre tüm büyükşehir belediyeleri arasında pay edilecektir.

Çizelge 10'da ayrıntılı bir biçimde gösterildiği gibi, Hatay Büyükşehir Belediyesi sınırları içinde yapılan genel bütçe vergi gelirleri tahsilatı toplamı, 2011 yılı rakamlarıyla tahmini olarak 2.977.523 lira seviyesindedir. Söz konusu genel bütçe gelirinin \% 6’lık diliminin \% 60’1 doğrudan Hatay Büyükşehir Belediyesi'ne aktarılırken, çizelgede de görüleceği gibi büyükşehir belediyeleri arasında oluşturulmuş olan havuzdan da Hatay Büyükşehir Belediyesi'ne nüfus ve yüzölçümüne göre pay aktarılmaktadır. Ayrıca su ve kanalizasyon idaresinden de aktarılan paylar göz önünde bulundurulduğunda, Hatay Büyükşehir Belediyesi’nin toplam olarak, yıllık üç yüz milyona yakın geliri söz konusudur.

Çizelge 10: 6360’a Göre Hatay Büyükşehir Belediyesi’nin Genel Bütçe Vergi

Gelirlerinden Alacağı Paylar (2011 Verilerine Göre)

\begin{tabular}{|l|c|l|l|l|l|l|l|l|}
\hline Birim & $\begin{array}{c}\text { GBVG } \\
(\text { Bin TL.) }\end{array}$ & $\begin{array}{r}\text { GBVG } \\
(\% 6\end{array}$ & $\begin{array}{l}\text { Doğrudan } \\
\text { Pay } \\
(\% 60)\end{array}$ & $\begin{array}{l}\text { Havuzdan } \\
\text { Pay } \\
(\% 70), \\
\text { Nüfus Ölç. }\end{array}$ & $\begin{array}{l}\text { Havuzdan } \\
\text { Pay (\%30), } \\
\text { Yüzölçümü } \\
\text { Ölç. }\end{array}$ & $\begin{array}{l}\text { BŞB’ye } \\
\text { İlçelerden } \\
\text { Gelen } \\
\text { Pay }\end{array}$ & $\begin{array}{l}\text { Su ve } \\
\text { Kn } \\
\text { İd.. den } \\
\text { Gelen } \\
\text { Pay }\end{array}$ & Toplam \\
\hline $\begin{array}{l}\text { Hatay } \\
\text { BŞB }\end{array}$ & 2.977 .513 & 127.496 & 76.497 & 85.404 & 20.832 & 85.530 & 28.510 & 296.773 \\
\hline
\end{tabular}

Kaynak: (TEPAV, 2013)

6360 sayılı Yasa'nın 25. Maddesi kapsamında,Genel Bütçe Vergi Gelirleri Tahsilâtı Toplamının \% 1,50'si büyükşehir dışındaki belediyelere aktarılırken, \% 4,50'si büyükşehirlerdeki ilçe belediyelerine aktarılmaktadır. Hatay Büyükşehir Belediyesi, bir yandan da \% 4.50 kapsamında Hatay'da bulunan tüm ilçe belediyelerine aktarılacak olan payların \% 30'unu alacaktır. 6360 sayılı Yasa'nın mali düzenlemeleri kapsamında hem Hatay Büyükşehir Belediyesi'nin gelirlerinde, hem deHatay'da bulunan tüm ilçe belediyelerinin gelirlerinde önemli artışlar yaşanacaktır.

\section{Çizelge 11: 6360'a Göre Hatay'da Bulunan İlçe Belediyelerinin Genel Bütçe Vergi}

Gelirlerinden Alacakları Paylar (2011 Verilerine Göre)

\begin{tabular}{|l|l|l|l|l|l|l|l|l|l|}
\hline İlçeler & Nüfus & $\begin{array}{l}\text { Yüzölçü } \\
\text { mü }\end{array}$ & $\begin{array}{l}\text { Nüfusa } \\
\text { Göre } \\
\text { Pay }\end{array}$ & $\begin{array}{l}\text { Yüzölçümü } \\
\text { ne } \\
\text { Göre Pay }\end{array}$ & $\begin{array}{l}\text { İçelerden } \\
\text { BŞB } \\
\text { Ayrılan }\end{array}$ & $\begin{array}{l}\text { BŞB } \\
\text { SK'lere } \\
\text { ayrılan }\end{array}$ & $\begin{array}{l}\text { GBVG } \\
\text { Transf } \\
\text { er } \\
\text { Payı }\end{array}$ & $\begin{array}{l}\text { Toplam } \\
\text { GVG }\end{array}$ & $\begin{array}{l}\text { Artış } \\
\text { Yüzd } \\
\text { esi }\end{array}$ \\
\hline Altınözü & 60.198 & 470 & 10.945 & 1.367 & 3.694 & 1.231 & 7,39 & 3,00 & 1,46 \\
\hline Antakya & 232.473 & 432 & 42.268 & 1.256 & 13.057 & 4.352 & 10,00 & 47,86 & -79 \\
\hline
\end{tabular}




\begin{tabular}{|l|l|l|l|l|l|l|l|l|l|}
\hline Belen & 29.549 & 131 & 5.373 & 381 & 1.726 & 575 & 3,45 & 5,07 & -32 \\
\hline Dörtyol & 114.471 & 324 & 20.813 & 942 & 6.527 & 2.176 & 13,05 & 18,79 & -31 \\
\hline Erzin & 40.228 & 360 & 7.314 & 1.047 & 2.508 & 836 & 5,02 & 7,90 & -36 \\
\hline Hassa & 54.261 & 516 & 9.866 & 1.500 & 3.410 & 1.137 & 6,82 & 3,45 & 0,98 \\
\hline İskenderu & 266.751 & 321 & 48.501 & 933 & 14.830 & 4.943 & 29,66 & 41,42 & -28 \\
\hline Kırıkhan & 104.779 & 849 & 19.051 & 2.468 & 6.456 & 2.152 & 12,91 & 18,83 & -31 \\
\hline Kumlu & 13.156 & 225 & 2.392 & 654 & 914 & 305 & 1,83 & 1,69 & 0,08 \\
\hline Reyhanlı & 87.877 & 413 & 15.978 & 1.201 & 5.154 & 1.718 & 10,31 & 16,11 & -36 \\
\hline Samandăg & 129.424 & 443 & 23.532 & 1.288 & 7.446 & 2.482 & 14,89 & 11,67 & 0,28 \\
\hline Yayladağı & 22.582 & 350 & 4.106 & 1.018 & 1.537 & 512 & 3,07 & 2,57 & 0,20 \\
\hline
\end{tabular}

Kaynak: (Adıgüzel, Tek, 2014 ). TEPAV'ın 2012 yılı verilerinden yararlanılarak hazırlanmıştır.

Hatay Büyükşehir Belediyesi’nin gelirlerinde yaşanacak artışlar konusunda Yıldız (2013), farklı rakamlar ve oranlar vermektedir. Çizelge 12'de görüleceği gibi, Yılız'a göre bu artışın, 2011 yılı verileri baz alınarak Hatay Büyükşehir Belediyesi ve tüm belediyeler için \% 83 oranında olacağ öngörülmektedir. Başka bir değerlendirmede ise Hatay Büyükşehir Belediyesi'nin gelirlerindeki artış \%58.2 oranında olacaktır (AKP, 2012). Ayrıca yerel basına yansıyan başka bir habere göre, Hatay Büyükşehir Belediyesi AKP grup başkan vekili, büyükş̧ehir belediyesinin ve HATSU'nun yıllık toplam bütçesinin 700 milyon lira olduğunu belirtmiştir (http://8gunhaber.com/).

Çizelge 12: 2011 Yılı Verileri Çerçevesinde Hatay'da 6360 Sayılı Yasanın Gelirlere Olan Etkisi

\begin{tabular}{|l|l|l|l|l|l|l|}
\hline \multirow{2}{*}{ Birim } & \multirow{3}{*}{ Nüfus } & \multicolumn{2}{|l|}{$\mathbf{6 3 6 0}$ Öncesi } & \multicolumn{2}{l|}{ 6360 Sonrası } & \\
\cline { 3 - 7 } & & Tahakkuk & Kişi & Tahakkuk & Kişi Başı(TL) & Artış Oranı \% \\
\hline Hatay İÖİ Tahakkuku & 1.480 .571 & 53.549 .677 & 36 & - & - & - \\
\hline Antakya Belediyesi & 213.581 & 46.179 .251 & 216 & - & - & - \\
\hline Tüm Belediyeler & 1.164 .243 & 272.993 .449 & 234 & 498.616 .381 & 381 & 83 \\
\hline İÖİ +Tüm Belediyeler & 1.480 .571 & 326.543 .126 & 221 & 498.616 .381 & 337 & 52 \\
\hline
\end{tabular}

Kaynak: (Yıldız, 2013) verileri kullanılarak hazırlanmıştır.

Tüm bunların yanında Hatay'da yeni kurulmuş olan Antakya, Arsuz, Defne ve Payas ilçe belediyelerine merkezi bütçe yedek ödenek tertibinden bir defaya mahsus olmak üzere, genel bütçe vergi gelirlerinden alacakları aylık payın üç katı kadar da ilave kaynak aktarılacaktır.

\subsection{KENTSEL YAPIYA ETKILLERI}

6360 sayılı Yasa, yeni bir büyükşehir dizgesi ve bu dizgeye bağlı olarak imar ve planlama konusunda yeni düzenlemeler getirmiştir. Hatay'da büyükşehir belediyesinin kurulması ile birlikte, bu yeni dizgeye koşut olarak imar ve planlama konusunda yeni sonuçlar ortaya çıkacaktır. İzci ve Turan'ın (2013:137) da vurguladıkları gibi, 5216 sayılı Yasa nazım planlarının hazırlanması konusunda büyükşehir belediyelerini, uygulama imar planlarının hazırlanması konusunda ise ilçe belediyelerini yetkilendirilmiştir. Ancak 5216 sayılı Yasa'nın kurgulamış olduğu bu dizge, imar ve planlama konusunda büyükşehir 
belediyeleri ile ilçe belediyeleri arasında bir takım sorunların yaşanmasına neden olmaktaydı. Yeni düzenleme ile birlikte bütün il sınırları belediye sınırı olacağı için büyükşehir belediyesi, imar ve planlama düzeninin başlıca sorumlusu olarak, ilçe belediyelerinin hazırlamış oldukları imar planlarını da denetleme yetkisine sahip olmuştur.

6360 sayılı Yasa'nın getirmiş olduğu yeni düzenleme imar ve planlama hizmetleri konusunda kimi üstünlüklere (İstanbul ve Kocaeli modeli gibi) sahip olmakla birlikte, diğer büyükşehirlerin hem nüfus hem de kapladıkları alan bakımından farklılıkları da göz önünde bulundurulmalıdır. Dolayısıyla büyükşehir merkezine uzak olan yerleşim birimlerine etkin ve verimli hizmet sunumu konusunda bir takım sorunların yaşanması olasıdır. İmar planlarının uygulama ve denetim araçlarının kullanılması bakımından coğrafi uzaklık hizmetin etkin ve verimli sunulmasını olumsuz etkileyebilecektir (Keleş, 2012; Gözler, 2013). Kentsel planlama konusunda 6360 sayılı Yasa'nın getirmiș olduğu yöntemi eleștiren Keleș (2012), bu yöntemin iki basamak arasındaki uyuşmazlıkların giderilmesine katkıda bulunmadığını, aynı zamanda büyükşehir ilçe belediyelerinin bir yerel yönetim birimi olarak sahip olmaları gereken özerklikle bağdaşmadığını belirtmektedir.

6360 sayılı Yasa ile Hatay il sınırları içerisindeki bütün imar ve planlama yetkilerinin tümüyle Hatay Büyükşehir Belediyesi'nin elinde toplanacak olması, gelecek dönemlerdeki imar uygulamalarına bağlı olarak, Keleş'in altını çizmiş olduğu bir takım sakıncaları beraberinde getireceği gibi, Hatay'a özgü bir takım kentsel sorunların çözümüne olumlu yönde katkılar da sağlayabilir. 2014 Yerel Seçimleri sonuçlarının biçimlendirdiği ve AKP'nin büyük bir çoğunlukta olduğu Hatay Büyükşehir Belediye Meclis profili, daha ilk toplantılarda işaretini verdiği gibi, imar düzenlemeleri konusunda da büyükşehir ve ilçe belediyeleri arasında sorunların yaşanmasına neden olabilir. Diğer yandan, imar ve planlama yetkisinin tek elde, Hatay Büyükşehir Belediyesi'nin elinde toplanmış olması, uzun yıllardır Antakya kentsel alanının bütünsellikten uzak bir anlayış içerisinde düzensiz ve plansız büyümesine neden olan sürecin sona ermesine vesile olabilir.

Süreç içerisinde, Hatay Büyükşehir Belediyesi ilin tüm yerleşim birimlerine eşit derecede beledi hizmet sunumu konusunda bir takım sorunlarla karşılaşabilecektir. Çünkü Hatay İli’nin coğrafi yapısıyerele özgü bir takım farklı sorunların ortaya çıkmasına neden olabilecek özelliklere sahiptir. Örneğin Hatay İli'nde, korunması gereken tarım alanlarının bulunduğu Amik Ovası'nın yanı sıra, geniş orman alanları, narenciye ve zeytin bahçeleri bulunmaktadır. Amanos Dağları'nın güney-doğusunda bulunan Amik Ovası'nın hızlı bir biçimde genişleyen Antakya merkezli kentleşme tehdidi altında olduğu bir gerçektir. Öte yandan dabu dağların kuzeyinde bulunan orman ve narenciye alanlarının ise İskenderun-Payas merkezli sanayinin tehdidi altında olduğu bilinmektedir. Ayrıca, Amanos Dağları'nın il topraklarını kuzeyden güneye inerek ikiye bölmüş olması ve büyükşehir belediyesi merkezinin bu dağların doğusunda, sanayi merkezinin ise ağırlıklı olarak batısında kalmış olması, coğrafi anlamda ulaşılabilirliği zorlaştıran bir engeldir. Bu coğrafi engel, yerel hizmetlerin tüm il sathına hızlı ve etkin bir şekilde ulaştırılabilmesini güçleştirecektir. $\mathrm{Bu}$ nedenle imar planlarının akılcı bir şekilde düzenlenmesi ve uygulanması ile birlikte, büyükşehir ve ilçe belediyeleri arasındaki eşgüdüm Hatay İli için çok daha özel bir önem taşımaktadır.

Yeni dizgeyle birlikte, büyükşehir belediyesinin nazım planlar hazırlama ve ilçe belediyelerinin hazırlamış olduğu uygulama imar planlarına onay verme yetkileri tarihi bir kent olan Antakya için özel önem arz etmektedir.Yeni büyükşehir yapısının, tarihi bir kent olan Antakya Kenti'nin tarihsel dokusu üzerine etkilerinin ne olacağı konusunda, yerel kamuoyunda büyük bir merak ve kaygı söz konusudur. Büyükşehir belediyesinin merkezinde bulunan Antakya Kenti'nin önemli uygarlıkların taşıyıcılığını yapabilmiş olması, Antakya Kenti'ne farklı bir önem kazandırmaktadır. Antakya Kenti'nin bu misyonu günümüz de devam etmektedir ki bu nedenle kentte çok önemli arkeolojik, kentsel ve doğal sit alanları bulunmaktadır. Antakya'nın geçmişi yetmişli yıllara dayanan "Koruma İmar Planı" bulunmaktadır ki bu plan sık sık revize edilerek günümüze gelebilmiştir. Bu nedenle, “Antakya Koruma İmar Planı”nın yeni büyükşsehir dizgesi doğrultusunda yeniden gözden geçirilmesi çok önemlidir. Daha da önemlisi Hatay Büyükşehir Belediyesi'nin nazım planlar hazırlama ve ilçe belediyelerinin hazırlamış olduğu uygulama imar planlarına onay verme yetkisi ve bu yetkinin doğru kullanılmasıdır.

6360 sayılı Yasa ile Hatay'da Antakya, Arsuz, Defne ve Payas ilçelerinin kurulmuş olması da kentleşme açısından önem arz etmektedir. Yeni kurulan ilçelerle birlikte ilde yeni bir demografik yapı ve 
dağılım ortaya çıkmıştır. Yeni yasa öncesinde 471 bin nüfusa sahip Merkez Antakya İlçesi'nde yeni düzenleme sonrasında 355 bin toplam nüfuslu Antakya İlçesi ve 115 nüfusa sahip Defne İlçesi kurulmuştur. Aynı şekilde, 320 bin nüfuslu İskenderun İlçesi de bölünmüş, ayrılma sonrasında İskenderun İlçesi'nin nüfusu 220 bine düşerken, 98 bin nüfusa sahip Arsuz İlçesi kurulmuştur. Dörtyol İlçesi’nin ise 152 bin olan toplam nüfusu, Payas'ın ilçe olmasıyla birlikte 114 bine düşerken, bu yeni ilçenin toplam 38 bin nüfusa sahip olduğu görülmektedir. Elbette ki ilçelerin sınırlarının değişmesi ve özellikle yeni ilçelerin kurulmuş olması, bu ilçelerin bulundukları alanlarda yeni kentsel hareketliliğin ortaya çıkmasına neden olmuştur. Çünkü bir yerleşim biriminin ilçeye dönüştürülmesi, o yerleşim alanında yeni kamu ve hizmet binalarının yapılmasını gerektirir ki bu da beraberinde kentsel devingenliğin artmasına neden olur. Üstelik bu yeni ilçe belediyelerinin Hatay Büyükşehir Belediyesi sınırları içerisinde bulunması, bu belediyelerin diğer illerde bulunan ilçe belediyelerine göre daha fazla mali kaynaklara sahip olması anlamına gelmektedir. Bu belediyeler, kendilerine tahsis edilecek olan kaynakları verimli kullandıkları takdirde daha sağlıklı ve yaşanabilir kentsel alanların ortaya çıkması da mümkün olacaktır.

6360 sayıl1 Yasa'ya göre, İstanbul ve Kocaeli hariç, büyükşehir, büyükşehir ilçe belediyeleri ve bağlı idareleri, yatırım bütçelerinin en az \%10'unu on yıl süre ile yasa kapsamında belediye sınırlarına yeni dahil olan yerleşim yerlerinin altyapı hizmetleri için ayırmaları ve kullanmaları konusunda zorunlu tutulmuştur. Bu kapsamda Hatay Büyükşehir Belediyesi kendi sınırlarına yeni dahil edilmiş olan Antakya, Defne, Arsuz ve Defne ilçelerinin altyapı hizmetleri için zorunlu olarak belli miktarlarda ödenek ayırmak zorunda kalacaklardır. Bu durumda, Hatay Büyükşehir Belediyesi sınırları içerisine dahil edilmiş olan yeni ilçelerin, gelecek dönemlerde belli standartlara sahip kentsel alanlar olarak dönüşebileceklerini söylemek mümkündür.

\section{SONUC VE ÖNERILER}

Günümüzde orta büyüklükte bir kent olan Antakya kenti, kurulduğu ilk dönemlerden itibaren tarihsel süreç içerisinde çok parlak dönemler yaşadığı gibi, gerek depremler gerekse uğradığı istilalar nedeniyle çok önemli yıkımlar da yaşamışırı. Antakya kenti yaşamış olduğu bu yıkımlara rağmen, beşiklik ettiği uygarlıkların önemli miraslarını kısmen de olsa günümüze kadar taşıyabilmiştir. Farklı uygarlıkların mirasını günümüze taşıma yeteneği gösterebilmiş olan Antakya kenti, yakın dönemlerde başlamış olan kaba ve öngörüsüz bir yönetim anlayışı ile karşı karşıya kalmıştır. Günümüz Antakya kentinin merkezine bulunduğu kentsel alan, uzun yıllardır "yönetilememe" sorunuyla yüz yüzedir. Antakya kentsel alanında böylesine sorunlu bir sürecin yaşanmasının en temel nedeni siyasal hesap çağrıştıran ve irrasyonel olarak oluşturulan yerel-yönetsel dizgedir. Nüfusu gittikçe artmakta olan bu kentsel alanda doksanlı yıların başlarından itibaren çok sayıda küçük belde belediyesi kurmak suretiyle, kentsel alanın merkezinde bulunan Antakya Belediyesi kuşatılmış ve nefes alamaz hale getirilmiştir. 400 binden fazla nüfusu barındıran Antakya kentsel alanında 20'ye yakın belde belediyesi, yetersiz kaynak ve personel yapıları, öngörüsüz ve vizyonsuz yönetim anlayışlarıyla yerel hizmet sunmaya çalışmışlardır. Zaten isteseler de bu küçük belediyelerin rasyonel bir belediyecilik yapabilmeleri söz konusu değilken, bu "sorunlu yerel dizge"yi yaratanların önceliklerinin, "rasyonel belediyecilik" olmadığı, yaşanılan süreçte ortaya çıkmıştır.

Yönetilemeyen çok parçalı Antakya kentsel alanı için en iyi çözüm, yerel kamuoyunun da üzerinde hemfikir olduğu gibi, büyükşehir belediyesinin kurulmasıydı. Büyükşehir belediyesi konusunda kamuoyunda bir beklenti oluşmakla birlikte, 5216 sayılı Büyükşehir Belediyesi Yasası'nın belirlemiş olduğu 750.000 nüfus ölçütü koşulu bu beklentilerin önünde en önemli engel teşkil etmekteydi. Çünkü Antakya kentsel alanı olarak nitelendirdiğimiz alanın toplam nüfusu 400.000 civarındaydı. Büyükşehir beklentisi içerisinde olan birçok orta büyüklükteki kentte de aynı sorun söz konusuydu ve bu sorun ya nüfus ölçütünün aşağı çekilmesi ya da çok daha farklı bir büyükşehir belediyeciliği yaklaşımı ile aşılabilecekti. 6360 sayılı Yasa, büyükşehir belediyesinin sınırlarını ilin mülki sınırları ile örtüştüren farklı belediyecilik anlayışı ile bu sorunun üstesinden gelen bir düzenleme olmuştur.

Yeni bir büyükşehir dizgesi içerisinde Hatay’da büyükşehir belediyesi kurulmasının il genelinde çok önemli etkileri oluştur. Öncelikle, Hatay İl Özel İdaresi'nin tüzel statüsü sona ermiştir. Ayrıca ilde bulunan 64 belde belediyesi ve 368 köyün tüzel yapılarına son verilerek bu belediye ve köyler bağlı bulundukları ilçelerin birer mahallesine dönüştürülmüşlerdir. Antakya, Defne, Arsuz ve Payas ilçeleri kurulmuş, bazı ilçelerin sınırları değiştirilmiş, toplam 11 olan içe sayısı 15'e yükselmiş, böylece Hatay İli'nde yeni çok 
farklı bir yerel-yönetsel yapı ortaya çıkmıştır. Bu yeni yapı çerçevesinde Hatay Büyükşsehir Belediyesi’nin kurulmuş olması, ili yalnızca yönetsel boyutuyla değil, siyasal, mali, kentsel ve sosyal boyutlarıyla da etkilemiştir.

2014 Yerel Seçimleriyle birlikte, yeni büyükşehir dizgesi hayat bulurken, yeni yerel dizgenin Hatay yerel siyaseti üzerinde de önemli etlikleri olmuştur. 2014 Yerel Seçimleri'nde, örneğin büyükșehir belediye başkanlığı seçimlerinde seçim çevresinin ilin mülki sınırı, ilçe belediye başkanlığında ise ilçenin mülki sınırı olması dolayısıyla küçük siyasal partiler çok önemli kayıplara uğramış, buna karşılık büyük siyasal partiler ise büyük başarılar elde etmişlerdir. Örneğin 2009 Yerel Seçimleri’nde Hatay'da yalnızca 4 ilçe belediye başkanlığı kazanmış olan AKP, 2014 seçimlerinde bu sayıy 11'e yükseltirken, CHP ilçe belediye başkanlığı sayısını 1'den 4'e yükseltmiş, buna karşılık MHP 2009 seçimlerindeki oy oranlarını yakalamasına rağmen 6 olan ilçe belediye başkanlığı sayısını 1'e düşürmüştür. Hatay BŞB Başkanlığı seçimini ise uygulamış olduğu aday taktiği nedeniyle kıl payı CHP kazanabilmiştir.

Hatay Büyükşehir Belediye Başkanlığı seçimleri AKP ve CHP'nin çekişmesine sahne olurken, büyükşehir belediye meclisi seçimlerinde AKP \%37.7, CHP \%36, MHP \%19.3, Saadet Partisi ise \%1.5 oranında oy almışlardır. Buna karşılık, büyükşehir belediye meclisinde çok farklı bir meclis profili ortaya çıkmış, meclis 50 AKP'li, 25 CHP'li, 11 MHP'li ve 1 Saadet Partili üyeden oluşmuştur. Seçim sonuçlarının Yüksek Seçim Kurulu kararı sonrasında kesinleşmesi ve büyükşehir belediye başkanının mazbatasını bir ay gecikmeyle alabilmesi, hem tüm yerel hizmetlerin akamete uğramasına yol açmış, hem de yerel seçim gerginliğinin devam etmesine neden olmuştur. Büyükșehir belediye başkanının CHP'li, meclis çoğunluğunun ise AKP'nin elinde olması, büyükşehir belediyesi meclis çalışmalarına da yansımıştır. Büyükşehir belediyesi meclisi, ilk toplantısında çoğunlukta olan AKP'li üyelerin, İçişleri Bakanlığı'nın tahsis etmiş olduğu "norm kadrolar" konusunda muhalefet ederek ret oyu vermeleri nedeniyle karar alamamıştır. Bu tıkanıklığın bir sonucu olarak, belediye encümenine atanması gereken üyeler atanamamış, ayrıca büyükşehir bünyesinde çalışmakta olan, ancak kadroları mecliste onaylanmayan işçilerin maaşları ödenememiştir. Meclis göreve başladıktan sonra üç kez olağanüstü toplanmasına rağmen bütçe sorunu çözülememiş, yalnızca norm kadrolarla ilgili konuda uzlaşma sağlanabilmiş̧tir (www. İskenderun.biz.tr, 2014; www. samandagkentgunlugu.com 2014).

Yeni büyükşehir dizgesiyle birlikte, hem Hatay Büyükşehir Belediyesi'nin hem de ilçe belediyelerinin mali kaynaklarında önemli oranlarda artışlar olmuş, imar, planlama, su ve kanalizasyon idaresi konusunda tüm yetkiler büyükşehir belediyesinde toplanmıştır. Bu kapsamda, büyükşehir belediyesi bünyesinde su ve kanalizasyon hizmetlerini tek elden yürütebilmek amaciyla da 29.05.2014 tarihinde, "Hatay Büyükşehir Belediyesi Su ve Kanalizasyon İdaresi Genel Müdürlügü̈" (HATSU) kurulmuştur. Gelecek dönemlerde, mali kaynaklar verimli bir şekilde kullanılabilir, imar ve planlama yetkisi tek elden ve çağdaş kentbilim ilkeleri doğrultusunda akılcı bir şekilde yürütülebilirse, Hatay uzun zamandır içerisinde bulunduğu kentsel sorunlarla baş edebilme olanağı yakalayabilecektir.

6360 sayılı Yasa ile Türkiye'de uygulana gelen büyükşehir yapısından farklı bir büyükşehir sistemi oluşturulması ve bu sistemin 2014 Yerel Seçimleriyle hayata geçirilmesi, tüm büyükşehirlerde olduğu gibi Hatay uygulamalarında da bir takım olumlu ve olumsuz sonuçlar yaratmış ve yaratmaya devam edecektir. Hatay Büyükşehir Belediyesi uygulamalarıyla ortaya çıkan ya da ortaya çıkması olası bulunan sorunlarla ilgili olarak bir takım öneriler geliştirmek mümkündür:

- 6360 sayılı Yasa'nın biçimlendirmiş olduğu yeni büyükşehir dizgesi, çok uzun geçmişi bulunan köy ve belde belediyelerinin tüzel kişiliklerini ortadan kaldırmak suretiyle yerel demokrasinin en önemli unsurlarından olan "katılım"ın azalmasına ve dar bir alana sıkışmasına neden olmuştur. 6360 dizgesiyle ilgili olan bu genel sorunu aşmak için, özellikle ilçe belediyeleri ve büyükşehir belediyesi meclislerinde üye sayısını arttırmanın yanı sıra, ilin tümünü yansıtacak bir profilde oluşturulmalarına çalışılmalıdır.

- 2014 Yerel Seçimleri sonucunda ortaya çıkan Hatay Büyükşehir Meclis yapısı, partilerin oy oranlarına paralel bir meclis aritmetiğinin oluşmadığının somut bir göstergesidir. $\mathrm{Bu}$ nedenle 
partilerin büyükşehir belediyesi meclisi seçimlerinde almış oldukları oy oranlarına uygun sayıda meclis üyesi kazanabilmelerini sağlayacak daha adil seçim çevreleri planlanmalıdır.

- Hatay Büyükşehir Belediyesi Meclis yapısını bir fırsata dönüştürmek Hatay için çok önemlidir. Hatay Büyükşehir Belediyesi Başkanı'nın CHP'li, meclis üye çoğunluğunun ise AKP'de olması, aslında tarihsel kökleri olan uzlaşma, hoşgörü ve birlikte yaşama geleneğinin en güzel örneklerini sergilemiş Hatay için, fursata dönüştürülebilir. Hatay Büyükşehir Belediye Meclisi, tüm Hatay'ın meclisi olduğu bilinciyle hareket ederek, tarihsel süreçte olgunlaşmış“uzlaşma kültürü”yle tüm ilin sorunlarını birlikte çözme gayreti içerisinde olmalıdır.

- Hatay İli’nin kendine özgü coğrafi özellikleri de Hatay Büyükşehir Belediyesi’nin tüm il sathında etkin bir hizmet sunumunu zorlaştıracaktır. Örneğin Amanos Dağları'nın il topraklarını kuzeyden güneye inerek ikiye bölmesi ve büyükşsehir belediyesi merkezinin ilin doğusunda, sanayi merkezinin ise ağırlıklı olarak batısında kalmış olması, belediye hizmetlerinin ulaşılabilirliğini zorlaştıran bir durum yaratmıştır. Bu coğrafi engel, yerel hizmetlerin tüm il sathına hızlı ve etkin bir şekilde ulaştırılabilmesini güçleştireceğinden dolayı, büyükşsehir ve ilçe belediyeleri eşgüdüm içerisinde hareket etmeli ve ilin farklı noktalarında her türlü kentsel alt yapı hizmeti görebilecek nitelikte "makine parkları" oluşturulmalıdır.

- Hatay İli’nin farklı coğrafi özellikleri yerele özgü bir takım farklı sorunların ortaya çıkmasına neden olabilir. Örneğin Hatay İli'nde, önemli tarım topraklarının olduğu Amik Ovası ile birlikte, geniş ormanlık alanlar, narenciye ve zeytin bahçeleri ve turizm için önemli potansiyeli olan kıyıları bulunmaktadır. Amik Ovası'nın hızlı bir biçimde genişleyen Antakya merkezli kentleşme tehdidi altında, kuzeyde bulunan orman ve narenciye alanlarının ise İskenderun-Payas merkezli sanayinin tehdidi altında olduğu bilinmektedir. Ayrıca Hatay'ın Akdeniz kıyısında olmasına rağmen, turizm potansiyelini değerlendiremediği ve kıyıların da tehdit altında olduğu tartışılmaktadır. Bu nedenle Hatay Büyükşsehir Belediyesi'nin en önemli önceliğinin, nazım planları ve bütüncül imar planları aracılığıyla tehdit altına olan bu alanları korumak olmalıdır.

Hatay Büyükşehir Belediyesi'nin merkezi olan Antakya Kenti'nin çok önemli uygarlıklara hem beşiklik hem de eşiklik eden tarihi bir kent olduğu bilinmektedir. Bu nedenle de kentte arkeolojik, kentsel ve doğal sit alanları bulunmakla birlikte, anıtsal ve sivil mimarlık örneği yüzlerce yapı tescil edilmiştir. Geçmiş dönemlerde sık sık revize edilmiş olan “Antakya Koruma İmar Planı”nın yeni büyükşehir koşulları doğrultusunda yeniden gözden geçirilmesi konusunda Hatay Büyükşehir Belediyesi öncülük etmeli, planın kapsamı genişletilmeli ve daha da güçlenmiş mali yapısıyla bu alanların korunmasına katkı yapmalıdır. Hatay Büyükşehir Belediyesi için tarihsel dokunun korunması, hem nazım planlar hazırlarken, hem de ilçe belediyelerinin uygulama imar planlarına onay verirken en önemli önceliklerinden olmalıdır 


\section{KAYNAKÇA}

ADIGÜZEL, Şenol, TEK, Murat (2011), "Büyükşehir Belediyesi Olma Sürecinde Antakya Metropoliten Alanında Yerel Siyaset”, Çağdaş Yerel Yönetimler Dergisi, Cilt:20, Sayı 4, s. 73-95.

ADIGÜZEL, Şenol, TEK, Murat (2014), “6360 Sayılı Yasa ile Türkiye’nin Büyükşehir Belediyesi Sisteminde Meydana Gelen Değişimler, Hatay Büyükşsehir Belediyesi Örneği”, (Bu çalışma, Çağdaş Yerel Yönetimler Dergisi Hakem Sürecinden Geçmiş Olup Yayımlanmayı Beklemektedir.)

AK PARTI GENEL MERKEZİ YEREL YÖNETIMLER BAŞBANLIĞI (2012), "Sorular ve Cevaplarla Yeni Büyükşehir Belediyesi Yasası, Erişim Tarihi: 20.05.2014

BÜYÜKȘEHİR BELEDIYYSSI KANUNU-3030, RG. 09.07.1984/18453

BÜYÜKȘEHİR BELEDIYESİ KANUNU -5216, RG. 23.07.2004/25531

DEMIR, Ataman (1996), Çağlar İçinde Antakya, Akbank Kültür ve Sanat Kitapları, İstanbul

GÖZLER, Kemal (2013), “6360 Sayılı Kanun Hakkında Eleştiriler, Yirmi Dokuz İlde İl Özel İdareleri ve Köylerin Kaldırılması ve İlçe Belediyelerinin Büyükşehir İlçe Belediyesi Hâline Dönüştürülmesi Anayasamıza Uygun Mudur?" (İnternet Erişim Tarihi, 21.02.2014), http://www.idare.gen.tr/6360elestiriler.pdf

GÜNEŞ, Muharrem (2004), “'Dayatmacı' Çözüm Yerine, 'Yerinden' Çözüm, Bir Sorun Bir Çözüm Önerisi, 'Bütünleşik Kent Yönetimi’”, Küreselleşme Klskacında Kent ve Politika, (Ed.: M. Güneş), s.204-223, Detay Yayınc1lık, Ankara.

İZCI, Ferit, MENAF, Turan (2013), “Türkiye'de Büyükşehir Belediyesi Sistemi ve 6360 Sayılı Yasa İle Büyükşsehir Belediyesi Sisteminde Meydana Gelen Değişimler: Van Örneği”, Süleyman Demirel Üniversitesi, IIBF Dergisi, s. 117-152.

KARA, Adem (2005), 19. Yüzyılda Bir Osmanlı Şehri: Antakya, IQ Kültür Sanat Yayıncılık, İstanbul.

KELEŞ, Ruşen (2004), Kentleşme Politikası, İmge Kitabevi, Ankara

KELEŞ, Ruşen (2012), “Anakentlerin Dünü, Bugünü ve Yarını”, Kentsel ve Bölgesel Araştırma Sempoyumu-3, 6-7 Aralık, 2012, Gazi Üniversitesi, Ankara.

MAHALLİ İDARELER GENEL MÜDÜRLÜĞÜ, [http://www.migm.gov.tr/Istatistik/Illerin Köy Sayilari. Pdf], Erişim Tarihi: 08.04.2014.

ON ÜÇ İLDE BÜYÜKŞEHIR BELEDIYYESİ VE YİRMİ ALTI İLÇE İLE BAZI KANUN HÜKMÜNDE KARARNAMELERDE DEĞIŞİKLIK YAPILMASINA DAİR KANUN,-6360, RG. 06.12.2012/28487

ÖZGÜR, Hüseyin ve Diğerleri (2007), “Türkiye'de Kentsel Alanların Yönetimi Sorunu”, Kamu Yönetimi Forumu, KAYFOR IV, Bildiriler Kitabı, Muğla Üniversitesi, Muğla.

TEK, Murat (2009a), "1980 Sonrası Hatay İlinde Kamu Yatırımları ve Kentleşmeye Etkisi Nicel Bir Değerlendirme", MKÜ SBE Dergisi, Cilt 6, Say1 12, s. 351-372.

TEK, Murat (2009b), Antakya'da Belde Belediyeleri Sorunu, Detay Yayınc1lı, Ankara. 
TEK, Murat (2009c), Hatay Yerel Seçimler Panoraması 1963-2004, Detay Yayıncılık, Ankara.

TEKİN, Mehmet (2008), "Hatay Tarihi”, Ekolojik Okur Yazarlık, (Ed.:Y.Ergün, Ş.Y. Özdilek, H. Pamir), s. 310-323, Mustafa Kemal Üniversitesi Yayınları, Hatay.

TEPAV (2012), 6360 Sayılı Yasaya Göre Belediyelerin Genel Bütçe Vergi Gelirlerinden Alacakları Paylar, (http://www.tepav.org.tr/upload/files/haber/1354287682-2.6360_Sayili_Yasaya_Gore

Belediyelerin_Genel_Butce_Vergi_Gelirlerinden_Alacaklari_Paylar.pdf 03.03.2014)

TEPAV (2013), 6360 Sayılı Yasaya Göre Belediyelerin Genel Bütçe Vergi Gelirlerinden Alacakları Paylar, http://www.tepav.org.tr/upload/files/haber/1354287682.6360_Sayili_Yasaya_Gore_Belediyelerin_Genel_Bu tce_Vergi_Gelirlerinden_Alacaklari_Paylar.pdf (03.03.2014)

TUİK (2012), 2012 Yılı Adrese Dayalı Nüfus Kayıt Sistemi Sonuçları, (http://tuikapp.tuik.gov.tr/adnksdagitapp/adnks.zul 13.03.2014)

TUIKK (2013), Mahalli İdareler Seçim Sonuçları, (http://tuikapp.tuik.gov.tr/secimdagitimapp/menuyerel.zul $03.02 .2014)$

ULUSOY, Ahmet, AKDEMİR, Tekin (2013), Mahalli İdareler, Teori-Uygulama-Maliye, Seçkin Yayınevi, Ankara.

YILDIZ, Mustafa (2013), “6360 Sayılı Onüç İlde Büyükşehir Belediyesi Ve Yirmialtı İlçe Kurulması İle Bazı Kanun ve Kanun Hükmünde Kararnamelerde Değiş̧iklik Yapılmasına Dair Kanun” Mahalli İdareler Genel Müdürlüğü,

(http://www.tuhis.org.tr/resim/files/mustafa_yild\%C4\%B1z_son\%281\%29.pdf 06.03.2014)

42 SERİ NOLU BELEDIYY GELIRLERİ KANUNU GENEL TEBLİ̆̇̆, RG. 31.12.2012/28514

http://www.bugun.com.tr/secim, Erişim Tarihi: 11.05.2014.

http://www.cnnturk.com/secim2014, Erişim Tarihi: 21.05.2014.

www.iskenderun.biz.tr/haber/ak-parti-hatay-buyuksehir./2778, Erişim Tarihi: 27.05.2014.

http: //www. samandagkentgunlugu.com /, Erişim Tarihi: 01.06.2014.

http://8gunhaber.com/butce-uygulamazsa-suc-duyurusunda-bulunacagız-10518, Erişim Tarihi: 19.05.2014. 